\title{
Temporal changes in North Atlantic circulation constrained by planktonic foraminiferal shell weights
}

\author{
Stephen Barker ${ }^{1}$ \\ Department of Earth Sciences, University of Cambridge, Cambridge, UK \\ Thorsten Kiefer and Henry Elderfield \\ Department of Earth Sciences, University of Cambridge, Cambridge, UK
}

Received 6 January 2004; revised 25 May 2004; accepted 25 June 2004; published 28 August 2004.

[1] Records of planktonic foraminiferal shell weights for Globigerina bulloides, covering Termination I from four proximal sites at waters depths from 1150 to $4045 \mathrm{~m}$ in the northeast Atlantic, demonstrate the influence of dissolution superimposed upon initial shell weight variability. Records of shell weight, unaffected by dissolution, may be used as a reference for interpreting deeper records in terms of preservation history. Combining records of planktonic shell weight (and benthic $\delta^{13} \mathrm{C}$ ) from shallow and deep sites suggests that maximum oceanic stratification and incursion of southern sourced deep waters in the North Atlantic occurred at about 18-20 ka, defining the glacial mode of Atlantic circulation. Reduced stratification and enhanced preservation in deeper waters reflect conditions during Heinrich event 1. A state similar to the modern mode of Atlantic circulation was attained by about $10 \mathrm{ka}$. INDEX TERMS: 1050 Geochemistry: Marine geochemistry (4835, 4850); 4267 Oceanography: General: Paleoceanography; 4825 Oceanography: Biological and Chemical: Geochemistry; 4283 Oceanography: General: Water masses; 4532 Oceanography: Physical: General circulation; KEYWORDS: foraminiferal shell weights, dissolution, North Atlantic circulation

Citation: Barker, S., T. Kiefer, and H. Elderfield (2004), Temporal changes in North Atlantic circulation constrained by planktonic foraminiferal shell weights, Paleoceanography, 19, PA3008, doi:10.1029/2004PA001004.

\section{Introduction}

[2] The use of shell weights of planktonic foraminifera as an indicator of dissolution in the deep ocean was proposed by Lohmann [1995] and has been developed by Broecker and Clark [2001a, 2001b] as a proxy for bottom water carbonate ion concentration, $\left[\mathrm{CO}_{3}^{=}\right]$. Weight loss, caused by dissolution of the carbonate tests of foraminifera, can be calibrated with bottom water $\left[\mathrm{CO}_{3}^{\overline{ }}\right]$ and used to reconstruct paleo- $\left[\mathrm{CO}_{3}^{-}\right]$gradients using cores from different water depths [Broecker and Clark, 2001a, 2001b].

[3] The shell weight method is based on a number of assumptions. One is the implicit assumption that foraminiferal dissolution is related to bottom water $\left[\mathrm{CO}_{3}^{\overline{ }}\right]$, ignoring supralysocline dissolution [Archer et al., 1989] unless a reasonably constant offset between bottom water and pore water $\left[\mathrm{CO}_{3}^{=}\right]$is assumed. Of more fundamental importance is the assumption that the "initial weights" of foraminiferal shells (i.e., before dissolution) are reasonably constant through time such that weight loss may be determined by comparison with core-top samples. However, it has been observed that there is significant variability in sizenormalized weights of foraminiferal shells from core tops recovered from shallow water depths [Barker and Elderfield, 2002]. This is thought to be due to the influence of carbonate saturation during shell growth, i.e., surface

\footnotetext{
${ }^{1}$ Now at Lamont-Doherty Earth Observatory, Columbia University, Palisades, New York, USA.
}

Copyright 2004 by the American Geophysical Union. 0883-8305/04/2004PA001004 water $\left[\mathrm{CO}_{3}^{\overline{ }}\right]$ [Spero et al., 1997; Bijma et al., 1999]. There may be additional causes of variability in "initial shell weight," such as growth habitat and food supply [Broecker and Clark, 2001a], but the influence of surface water $\left[\mathrm{CO}_{3}^{\overline{-}}\right]$ is strongly supported by observations that glacial age shells from the North Atlantic were significantly heavier than those of Holocene age and that this increase could be attributed to the glacial increase in surface ocean $\left[\mathrm{CO}_{3}^{\overline{1}}\right]$ in line with lowered glacial atmospheric $\mathrm{CO}_{2}$ [Barker and Elderfield, 2002].

[4] Given the variability in the shell weights of undissolved foraminifera, it follows that, before records of shell weight may be interpreted in terms of dissolution and bottom water $\left[\mathrm{CO}_{3}^{\bar{z}}\right]$ variability, they must be adjusted to allow for changes in initial weight. The most straightforward means of achieving this is to use the record of a shallow site, located well above the lysocline, as a reference site. Here, we apply this method using records of shell weight from four sites on a depth transect from 1150 to $4045 \mathrm{~m}$ in the North Atlantic. Our approach is to use the record of shell weight at the shallowest site to constrain initial weight variability and apply this to interpret deeper records in terms of weight loss and dissolution. Using records rather than time slices means we are able to track the evolution of deep water $\left[\mathrm{CO}_{3}^{=}\right]$through time.

\section{Background and Methods}

2.1. Cores and Analytical Methods

[5] The cores used in this study were chosen to span a significant range in water depth within a limited geograph- 


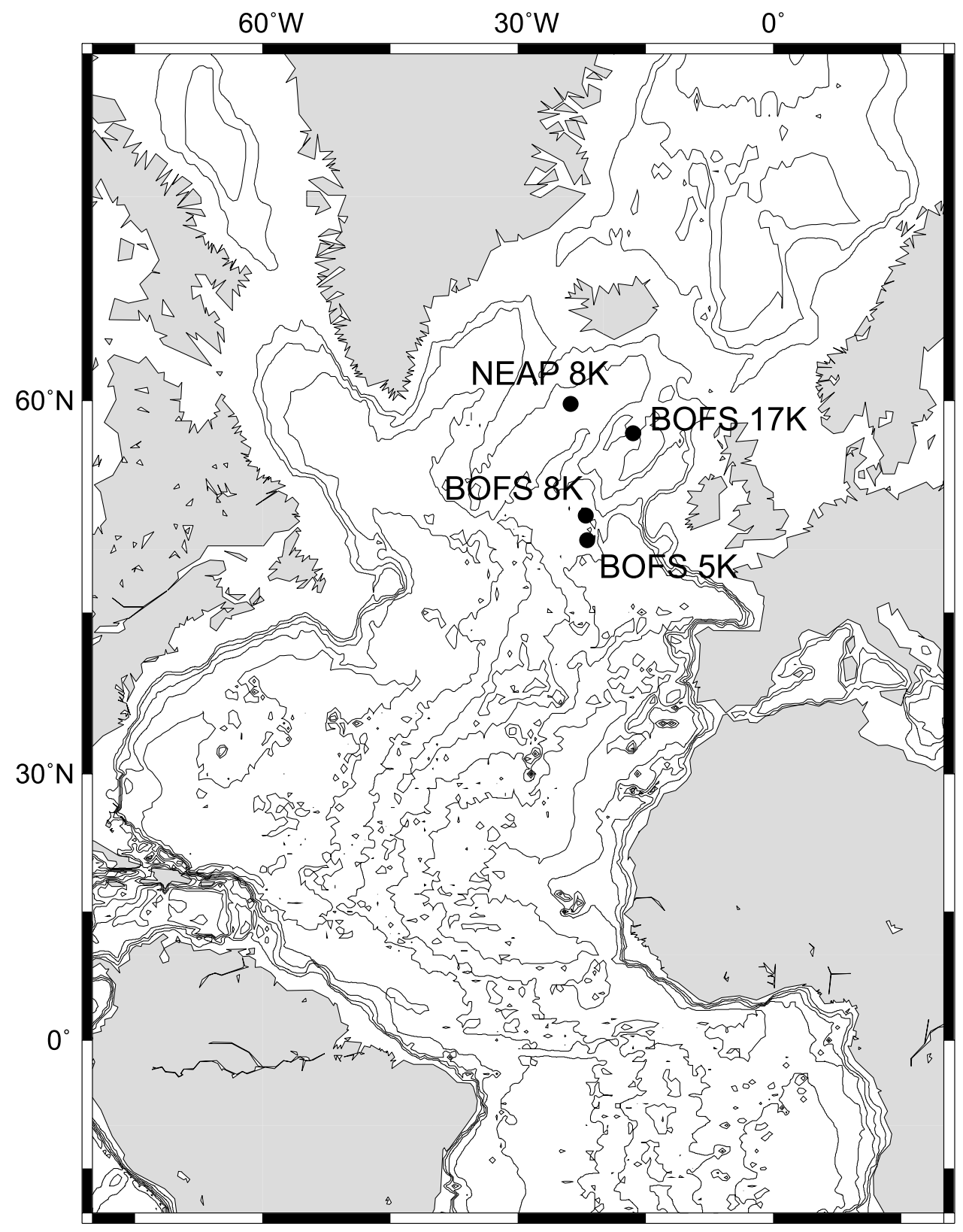

Figure 1. Locations of the four cores used in this study. Details are given in Table 1.

ical area in the northeast Atlantic Ocean (Figure 1, Table 1) under the assumption that the shell weight records from each core would have been similar before post depositional alteration by dissolution. The choice of cores was partially determined by the availability of preexisting proxy data to aid in cross correlation between cores and development of age models [Manighetti et al., 1995; Maslin et al., 1995].

[6] Tests of G. bulloides were picked from prewashed core sediment sieved to $300-355 \mu \mathrm{m}$. For weight analysis an ideal sample contained about 50 individual tests. However, the abundance of $G$. bulloides during glacial intervals in these cores is very low [Maslin et al., 1995]. Therefore fewer tests were used where numbers were limited although no sample contained less than 10 individual tests. Weight measurements were made using a microbalance $(0.1 \mu \mathrm{g})$. We estimate the error associated with natural variation to be about $\pm 0.5 \mu \mathrm{g}$. Size analysis was performed on digital photomicrographs of individual sample populations. Each image contained the same set of reference shells allowing postanalysis correction for variations in light intensity and

Table 1. Core Locations for the Present Study

\begin{tabular}{cccc}
\hline Core ID & Latitude, deg N & Longitude, deg W & Water Depth, m \\
\hline BOFS 17K & 58.0 & 16.5 & 1150 \\
NEAP 8K & 59.8 & 23.8 & 2360 \\
BOFS 5K & 50.7 & 21.9 & 3547 \\
BOFS 8K & 52.5 & 22.1 & 4045 \\
\hline
\end{tabular}


focusing precision. The day to day precision of reference shell measurements was generally better than $0.5 \%$ for length determinations. This compares with downcore variations of $>10 \%$. Stable isotope measurements of $\mathrm{O}$ and $\mathrm{C}$ were made by $\mathrm{M}$. Hall at the Godwin Laboratory, Cambridge. Scanning electron microscope (SEM) images of foraminiferal shells were made using a Jeol JSM 820.

\subsection{Age Model Development}

[7] The existing radiocarbon-based age model for BOFS 5K [Manighetti et al., 1995; Maslin et al., 1995] was revised in order to improve the chronological precision across the last deglacial. This chronology was then adopted for the other cores by cross-correlation. A general stratigraphic framework for BOFS $5 \mathrm{~K}$ was attained from the percentage maximum of ice rafted debris (IRD) defining Heinrich layer (HL) $1(62-78 \mathrm{~cm})$ and HL $2(106-108 \mathrm{~cm})$, and from a maximum of Vedde ash particles $(46-52 \mathrm{~cm}$; semiquantitatively determined on the $>150 \mu \mathrm{m}$ size fraction) marking the Younger Dryas (Figure 2). To obtain a more precise chronology, we recalibrated the planktonic ${ }^{14} \mathrm{C}$ ages of Manighetti et al. [1995] with the CALIB program (version 4.3) [Stuiver and Reimer, 1993; Stuiver et al., 1998] and with the data set of Voelker et al. [2000] in the case of the ${ }^{14} \mathrm{C}$ age $>20,000{ }^{14} \mathrm{C}$ years at $114 \mathrm{~cm}$ (Table 2). Instead of correcting the measured ${ }^{14} \mathrm{C}$ ages with a constant reservoir age of 400 years [Bard, 1988; Manighetti et al., 1995] we applied a local paleoreservoir age of $1900{ }^{14} \mathrm{C}$ years at the base of HL1 [Waelbroeck et al., 2001] and $800{ }^{14} \mathrm{C}$ years at the top of the YD [Haflidason et al., 2000; Waelbroeck et al., 2001].

[8] Dates were omitted from the age model at three levels: (1) The G. inflata date at $44 \mathrm{~cm}$ was ignored because it is about 5 ka too old for unknown reasons [Manighetti et al., 1995]. (2) The two G. bulloides dates at 73 and $74 \mathrm{~cm}$ were derived from a minimum in G. bulloides abundance below a fivefold abundance increase at $70 \mathrm{~cm}$. As a result of downward mixing of Bølling-aged G. bulloides tests into HL1 [Manighetti et al., $1995]$ their ages are about 1 ka reservoir-corrected ${ }^{14} \mathrm{C}$ years younger than the corresponding $N$. pachyderma (s) also dated at $74 \mathrm{~cm}$ (Table 2). Although N. pachyderma (s) was dated from within an abundance decrease and might therefore be slightly biased toward being too old, we used this date in our age model because it provided a reasonable age estimate for HL1. (3) The date of $23.36 \mathrm{cal} \mathrm{ka}$ at $100 \mathrm{~cm}$ appeared several hundred years too old for its position $5 \mathrm{~cm}$ below HL2. Given the relatively poor calibration of ${ }^{14} \mathrm{C}$ dates below $13.0{ }^{14} \mathrm{C}$ ka [Stuiver et al., 1998] and to avoid improbable fluctuations in sedimentation rates we instead correlated the top of HL2 at $105 \mathrm{~cm}$ to the onset of the Dansgaard-Oeschger interstadial 2 at 23.53 cal ka [Stuiver and Grootes, 2000].

[9] No ${ }^{14} \mathrm{C}$ date was available between the base of HL1 and the top of the YD (74-46 cm). Here, an additional age constraint was provided by a maximum in right-coiling over total $N$. pachyderma at $60 \mathrm{~cm}$, which was assumed to represent the Bølling warm spell and, accordingly, was assigned an age of $14.5 \mathrm{cal}$ ka [Stuiver and Grootes, 2000].

[10] The revised age model results in the Vedde ash and a concomitant IRD maximum being in line with dates for the YD [Stuiver and Grootes, 2000] and the IRD maximum and meltwater-induced planktonic $\delta^{18} \mathrm{O}$ minimum of HL1 in line with dates for Heinrich event 1 [Bard et al., 2000]. Moreover, the $N$. pachyderma coiling ratios as an approximation of paleo-SST closely match the $\delta^{18} \mathrm{O}$ based temperature record from Greenland [Stuiver and Grootes, 2000] (Table 2).

[11] As discussed above, the ages of G. bulloides at 73/74 $\mathrm{cm}$ are biased by bioturbation and are therefore too young with respect to other sediment components (e.g., IRD and $N$. pachyderma (s)). However, they may represent a good average age for G. bulloides at that core depth. Therefore an alternate G. bulloides-specific age model was constructed for comparison. This age model uses an average of the G. bulloides ages at 73 and $74 \mathrm{~cm}$ instead of the N. pachyderma (s) age at $74 \mathrm{~cm}$ and does not include the nearby $N$. pachyderma coiling ratio maximum as an age marker.

[12] Owing to their close proximity, the chronology for BOFS $8 \mathrm{~K}$ could be derived from BOFS $5 \mathrm{~K}$ by correlation of their IRD concentrations (Figure 2a). Use of this correlation is supported by the good agreement of coiling ratios in N. pachyderma (Figure 2b). BOFS 17K and NEAP $8 \mathrm{~K}$ are located significantly to the north of the main IRD belt [Bond et al., 1992] and so no useful correlations could be made using percent IRD. Instead the benthic oxygen isotope records of BOFS $17 \mathrm{~K}$ and BOFS $8 \mathrm{~K}$ were used to crosscorrelate between these two cores (Figure 2c). The oxygen isotope records for $G$. bulloides were used to correlate between NEAP $8 \mathrm{~K}$ and BOFS $17 \mathrm{~K}$ since these two cores are fairly proximal to one another (Figure 2d). Age models for BOFS $8 \mathrm{~K}, 17 \mathrm{~K}$ and NEAP $8 \mathrm{~K}$ are given in Table 3.

\subsection{Correction of Weight Data for Size Variability}

[13] The shell weight method makes use of narrow size fractions to limit weight variability due to varying shell size (hence the notion of size normalized weight). Considerable size variability can occur even within a fairly narrow sieve size range [Elderfield and Barker, 2001] and can lead to significant weight variability within a single sample if strict control on the specific morphotype selected is not employed. This can be addressed by measuring the length and crosssectional area of individual shells within a sample population and using these measurements to apply a size normalization to samples [Barker and Elderfield, 2002].

[14] Measured shell lengths from BOFS 17K show no particular trend through time (Figure 3). Those from BOFS $8 \mathrm{~K}$ reveal that glacial age tests are significantly (up to $10 \%$ ) smaller than those from the Holocene section of the core. As discussed later, the glacial section of BOFS $8 \mathrm{~K}$ has suffered significant dissolution. Therefore it seems likely that the reduction in size is due to the loss of carbonate from the outer surface of the test during dissolution (see section 3.2). Since this phenomenon is a primary consequence of dissolution, it seems sensible not to correct for it. It is therefore suggested that the size normalization procedure employed by Barker and Elderfield [2002] should not be used if dissolution is suspected. We used an optimum sample size of 50 individuals for this study. This is the same as used by Broecker and Clark [2001a, 2001b] and should be sufficient to overcome the greater proportion of natural size variability without further normalization. The results for NEAP $8 \mathrm{~K}$ are from Barker and Elderfield [2002] where only 24 individuals were used. Since we do not expect significant dissolu- 


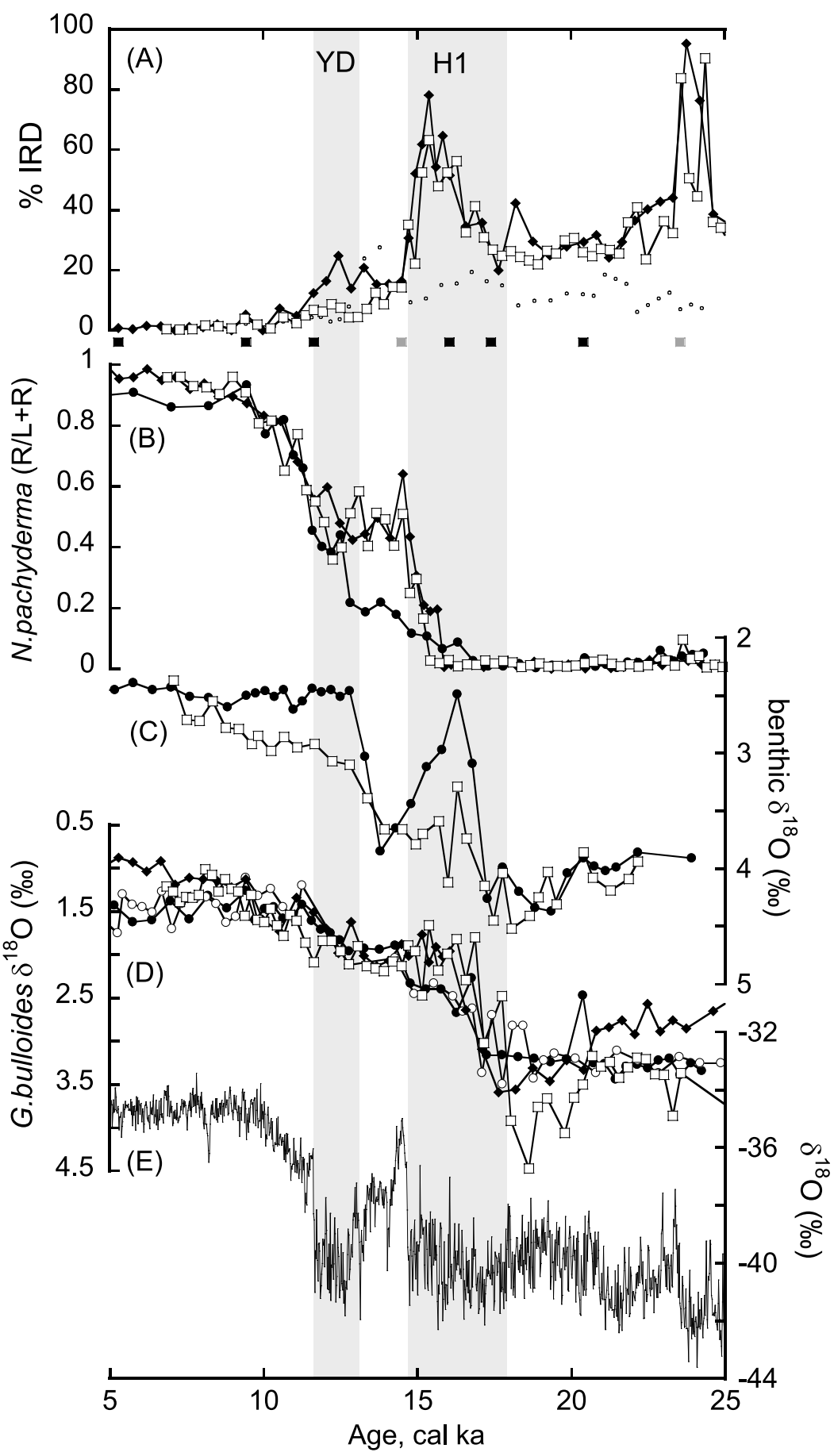

Figure 2. For all parts; solid circles represent BOFS 17K, hollow circles are NEAP 8K, solid diamonds are BOFS 5K, and hollow squares are BOFS 8K. (a) Percent IRD from BOFS $5 \mathrm{~K}$ and $8 \mathrm{~K}$ used for correlation. Also shown are data from BOFS 17K (small circles in this case) (data from Maslin et al. $[1995]) .{ }^{14} \mathrm{C}$ age measurements for BOFS $5 \mathrm{~K}$ are indicated by black squares. Gray squares indicate other dating constraints described in the text. (b) Coiling ratios for $N$. pachyderma for the BOFS cores (data from Maslin [1992]). BOFS 5K and 8K show a warming at the onset of the Bølling interstadial. (c) Benthic $\delta^{18} \mathrm{O}$ data from BOFS $17 \mathrm{~K}$ and BOFS $8 \mathrm{~K}$. (d) The $\delta^{18} \mathrm{O}$ from G. bulloides for the four cores (data for the BOFS cores are from Manighetti et al. [1995]; data for NEAP 8K are from the NEAPACC data CD). See text for full description of age model development. (e) $\delta^{18} \mathrm{O}$ from the GISP2 ice core [Stuiver and Grootes, 2000]. 
Table 2. Age Model for BOFS $5 \mathrm{~K}$

\begin{tabular}{|c|c|c|c|c|c|c|c|c|c|}
\hline \multicolumn{2}{|c|}{${ }^{14} \mathrm{C}$ Ages } & \multirow[b]{2}{*}{${ }^{14} \mathrm{C}$ Age } & \multirow[b]{2}{*}{$\begin{array}{c}\text { Reservoir } \\
\text { Age }\end{array}$} & \multirow[b]{2}{*}{$\begin{array}{l}\text { Corrected } \\
{ }^{14} \mathrm{C} \text { Age } \\
\end{array}$} & \multirow[b]{2}{*}{$\begin{array}{c}\text { Calibrated } \\
\text { Ages }\end{array}$} & \multirow[b]{2}{*}{$\begin{array}{c}\text { Calibration } \\
\text { Used }\end{array}$} & \multicolumn{2}{|c|}{ Age Model } & \multirow[b]{2}{*}{ Comment $^{\mathrm{a}}$} \\
\hline Depth, cm & Foram Species & & & & & & $\begin{array}{c}\text { Depth, } \\
\mathrm{cm}\end{array}$ & $\begin{array}{c}\text { Cal } \\
\text { Age, kyr }\end{array}$ & \\
\hline 0 & G. bulloides & $2020 \pm 140$ & 400 & 1620 & 1567 & Calib 4.3 & 0 & 1.57 & \\
\hline 20 & G. inflata & $4970 \pm 130$ & 400 & 4570 & 5300 & Calib 4.3 & 20 & 5.3 & \\
\hline 38 & G. bulloides & $8860 \pm 130$ & 400 & 8460 & 9436 & Calib 4.3 & 38 & 9.44 & \\
\hline 44 & G. inflata & $14970 \pm 180$ & 400 & 14570 & & & & & A \\
\hline 46 & G. bulloides & $11180 \pm 150$ & 800 & 10380 & $12097,12012,11971$ & Calib 4.3 & 46 & 11.64 & B \\
\hline 46 & N. pachyderma $(\mathrm{s})$ & $10770 \pm 130$ & 800 & 9370 & $11322,11243,11197$ & Calib 4.3 & 46 & 11.64 & B \\
\hline & & & & & & & 60 & 14.5 & $\mathrm{C}$ \\
\hline 73 & G. bulloides & $12860 \pm 150$ & 400 & 12460 & 14322 & Calib 4.3 & & & $\mathrm{D}$ \\
\hline 74 & G. bulloides & $12990 \pm 160$ & 400 & 12590 & $15068,14747,14378$ & Calib 4.3 & & & $\mathrm{D}$ \\
\hline 74 & N. pachyderma $(\mathrm{s})$ & $15370 \pm 180$ & 1900 & 13470 & 16064 & Calib 4.3 & 74 & 16.06 & \\
\hline 78 & N. pachyderma $(\mathrm{s})$ & $16520 \pm 180$ & 1900 & 15720 & 17388 & Calib 4.3 & 79 & 17.38 & E \\
\hline 80 & N. pachyderma $(\mathrm{s})$ & $16510 \pm 170$ & 1900 & 15710 & 17376 & Calib 4.3 & 79 & 17.38 & E \\
\hline 90 & N. pachyderma $(\mathrm{s})$ & $17650 \pm 220$ & 400 & 17250 & 20414 & Calib 4.3 & 90 & 20.41 & \\
\hline 100 & N. pachyderma $(\mathrm{s})$ & $20210 \pm 280$ & 400 & 19810 & 23360 & Calib 4.3 & & & $\mathrm{~F}$ \\
\hline & & & & & & & 105 & 23.53 & G \\
\hline 114 & N. pachyderma $(\mathrm{s})$ & $22960 \pm 330$ & 400 & 22560 & 25500 & Voelker et al. [2000] & 114 & 25.5 & \\
\hline
\end{tabular}

${ }^{a}$ Comments are as follows: A, rejected as too old [Manighetti et al., 1995]; B, average of calibrated ages of Nps and Gb dates; C, N. pachyderma coiling ratio max. correlated to Bølling in GISP2; D, culled because of downcore mixing [Manighetti et al., 1995], used in bulloides-specific age model; E, average of 78 and $80 \mathrm{~cm}$; F, culled because slightly too old with respect to top H2; G, top H2 correlated to DO2 warming in GISP2.

tion at this site we use the size normalized data of Barker and Elderfield [2002].

\subsection{Correction for Latitudinal Offsets}

[15] The basis for correcting for initial weight variability is that the weight records of the deeper cores would have been the same as the shallowest core had no weight loss by dissolution occurred. For this reason, our chosen core locations occupy a fairly limited geographical region. However, the bathymetry of the North Atlantic and the availability of suitable core material results in core sites spanning several degrees of latitude. Because modern shell weights vary with surface water $\left[\mathrm{CO}_{3}^{=}\right]$which itself varies with latitude (Figure 4), initial shell weights from the more southerly cores are expected to be slightly heavier than those from the more northerly sites. In order to incorporate this offset into our study, we have made a correction to three of the four cores (the most northerly site, that of NEAP $8 \mathrm{~K}$, being taken as the reference location) using a straightforward relation between shell weight and latitude:

$$
\text { shell weight }=42.2 \times \exp (-0.0228 \times \text { N.Lat }) .
$$

For the most southerly site (BOFS 5K) the correction decreases initial shell weights by $2.5 \mu \mathrm{g}$. We cannot predict

Table 3. Age Models for BOFS $8 \mathrm{~K}, 17 \mathrm{~K}$, and NEAP $8 \mathrm{~K}$

\begin{tabular}{|c|c|c|c|c|c|}
\hline \multicolumn{2}{|c|}{ BOFS $8 \mathrm{~K}$} & \multicolumn{2}{|c|}{ BOFS $17 \mathrm{~K}$} & \multicolumn{2}{|c|}{ NEAP $8 \mathrm{~K}$} \\
\hline $\begin{array}{c}\text { Depth, } \\
\mathrm{cm}\end{array}$ & $\begin{array}{l}\text { Age, } \\
\text { cal ka }\end{array}$ & $\begin{array}{c}\text { Depth, } \\
\mathrm{cm}\end{array}$ & $\begin{array}{l}\text { Age, } \\
\text { cal ka }\end{array}$ & $\begin{array}{c}\text { Depth, } \\
\mathrm{cm}\end{array}$ & $\begin{array}{l}\text { Age, } \\
\text { cal ka }\end{array}$ \\
\hline 20 & 8.98 & 0 & 0.89 & 0 & 0 \\
\hline 40 & 11.09 & 28 & 9.44 & 118 & 9.44 \\
\hline 64 & 14.5 & 50 & 12.80 & 136 & 11.27 \\
\hline 72 & 15.39 & 64 & 16.29 & 138 & 12.80 \\
\hline 80 & 16.59 & 70 & 17.76 & 144 & 14.29 \\
\hline 126 & 23.32 & 80 & 20.39 & 162 & 17.27 \\
\hline 136 & 24.62 & 90 & 22.15 & 196 & 22.85 \\
\hline 174 & 29.35 & & & & \\
\hline
\end{tabular}

how the relation between shell weight and latitude might vary with time; for example, changes in surface temperature or nutrient gradients between sites might cause offsets to vary through time. However, it is difficult to asses how such changes might affect the results from this study and therefore we make the assumption here that the offsets

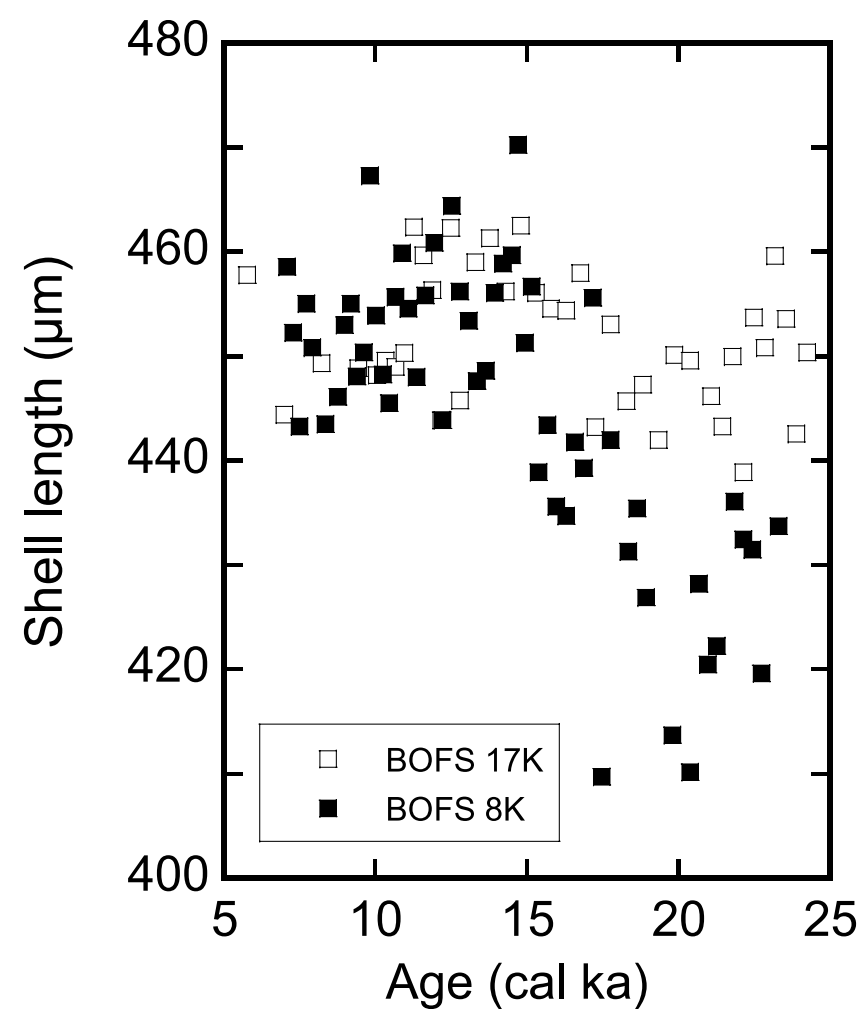

Figure 3. Measured shell lengths from BOFS $17 \mathrm{~K}$ and $8 \mathrm{~K}$. Shells from the glacial section of BOFS $8 \mathrm{~K}$ are significantly smaller than during the Holocene as a result of partial dissolution. 


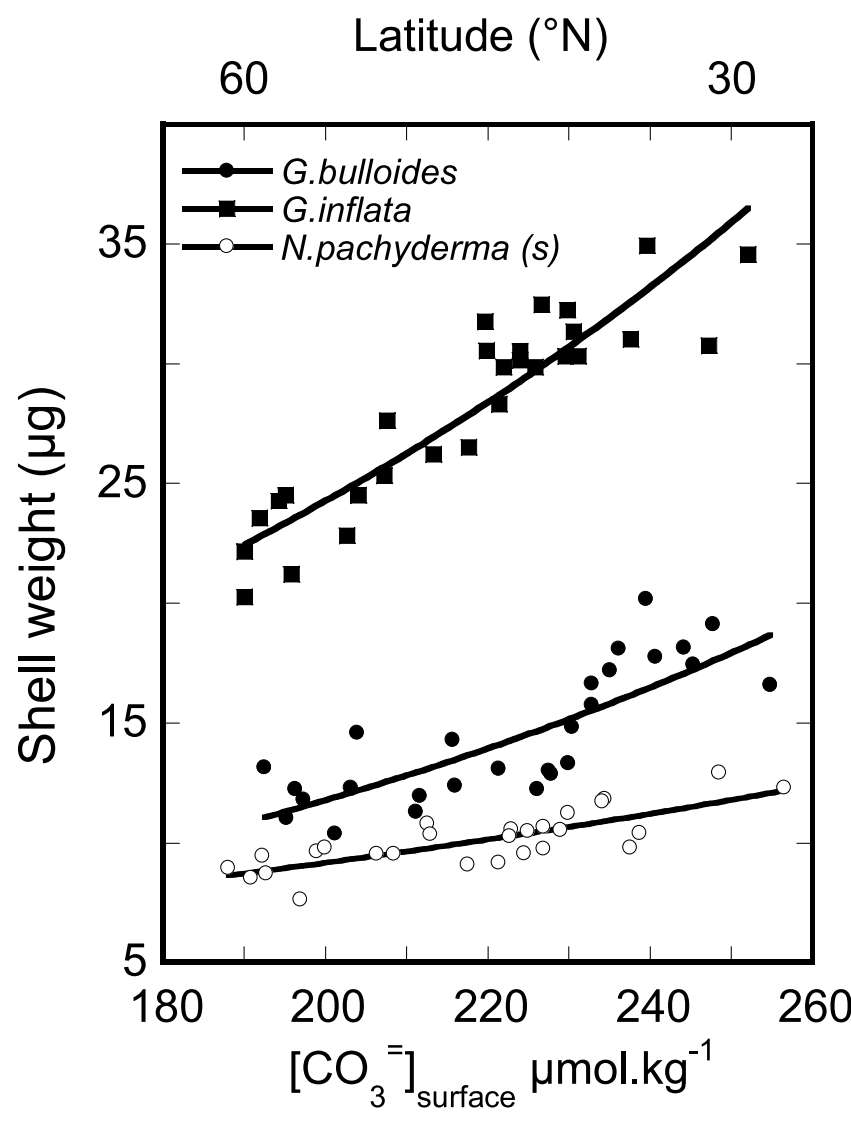

Figure 4. Shell weights for three species of planktonic foraminifera plotted against surface ocean $\left[\mathrm{CO}_{3}^{\bar{z}}\right]$ and latitude. The southward increase in surface ocean $\left[\mathrm{CO}_{3}^{=}\right]$ in the modern North Atlantic is due mainly to the increases in temperature and the ratio of alkalinity to dissolved inorganic carbon between 60 and $30^{\circ} \mathrm{N}$. The relation between weight and latitude for $G$. bulloides was used to correct for offsets between the core sites [after Barker and Elderfield, 2002].

between core sites remain constant. All subsequent calculations are performed on the adjusted data.

\subsection{Calibration of Shell Weight Loss With Bottom Water $\left[\mathrm{CO}_{3}^{=}\right]$}

[16] At present there is no calibration of weight loss versus bottom water $\left[\mathrm{CO}_{3}^{\bar{c}}\right]$ available for $G$. bulloides. Broecker and Clark [2003] present a revised calibration for G. sacculifer after the comments of Bijma et al. [2002] concerning the depth dependency of calcite saturation. Since $G$. sacculifer and $G$. bulloides are closely ranked in Berger's [1970] solubility index (5th and 8th out of 22 respectively), we have used Broecker and Clark's [2003] calibration for G. sacculifer in this work.

\subsection{Delta Records}

[17] Shell weight data (and also benthic $\delta^{13} \mathrm{C}$ measurements) from NEAP $8 \mathrm{~K}$, BOFS $5 \mathrm{~K}$ and BOFS $8 \mathrm{~K}$ (the deeper cores) were subtracted from data from BOFS $17 \mathrm{~K}$ (the shallowest core) to provide records of difference (delta records). Absolute records were first converted to a common timescale by sampling at 100 year intervals using a linear interpolation algorithm so that differences could be calculated on the common timescale. Delta records were not calculated on records later than $9.5 \mathrm{ka}$ since the relative age control within the Holocene sections of these cores is not sufficiently robust. By converting absolute records to records of difference, it is possible to visually appreciate the evolving gradients between the shallow and deep sites through time. An advantage of using records of $\Delta$ shell weight is that the difference between weight records describes variations in preservation between the two sites irrespective of how the record from the shallow site is interpreted. The same is true for $\Delta \delta^{13} \mathrm{C}$ in that global changes in $\delta^{13} \mathrm{C}$, superimposed upon the absolute records will be cancelled out.

\section{Results and Discussion}

\subsection{Modes of Atlantic Deep Ocean Circulation}

[18] Circulation in the Atlantic ocean is thought to have three distinct modes of operation; modern, glacial and Heinrich [Sarnthein et al., 1994; Alley and Clark, 1999; Rahmstorf, 2002]. In the modern mode, North Atlantic Deep Water (NADW) forms in the Nordic Seas and flows south to fill the North Atlantic with low nutrient water down to abyssal depths. During the last glacial period (glacial mode) deep water formation shifted southward and was constrained to shallower depths (producing Upper North Atlantic Deep Water, UNADW) by the incursion of high nutrient deep water sourced from the south, so-called Southern Ocean Water (SOW). This gave rise to a strong vertical nutrient gradient in the glacial North Atlantic as compared with the rather homogenous water mass observed today [e.g., Boyle and Keigwin, 1982; Oppo and Lehman, 1993; Sarnthein et al., 1994]. During the Heinrich mode of circulation, deep water formation essentially ceases and the North Atlantic may be filled by waters of Antarctic origin [Vidal et al., 1997; Zahn et al., 1997; Elliot et al., 2002]. There is some debate over which mode of the MOC dominated during the Younger Dryas (YD) period [Jansen and Veum, 1990; Veum et al., 1992; Lehman and Keigwin, 1992; Boyle, 1995]. Evidence from the western North Atlantic basin suggests a dramatic reduction in NADW production during the YD [e.g., Boyle and Keigwin, 1987; Keigwin et al., 1991] whereas cores from the eastern North Atlantic tend to lack a distinct deep water YD signal [Jansen and Veum, 1990; Veum et al., 1992; Sarnthein et al., 1994]. This may indicate that a change in circulation at this time was restricted to the western basin or that low sedimentation rates and bioturbation have combined to remove the signal in other records [Boyle, 1995; Alley and Clark, 1999].

[19] Benthic $\delta^{13} \mathrm{C}$ measurements were made on BOFS 8K (this study) and BOFS 17K [Bertram et al., 1995] (Figure 5). Holocene benthic $\delta^{13} \mathrm{C}$ values are similar for the two cores (around 1\%o) and agree with other studies suggesting a fairly homogeneous water column with respect to $\delta^{13} \mathrm{C}$ and nutrient concentrations [Kroopnick, 1980; Sarnthein et al., 1994; Beveridge et al., 1995]. During the glacial and deglacial periods the two records display very different trends. The 


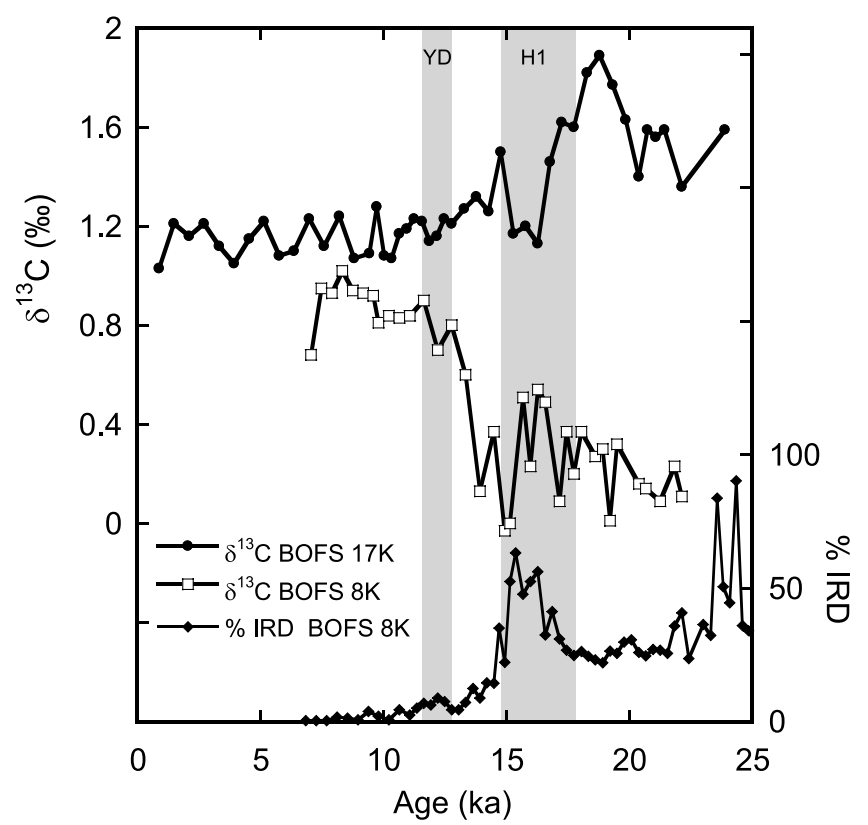

Figure 5. Benthic $\delta^{13} \mathrm{C}$ data from BOFS $17 \mathrm{~K}$ (Cibicidoides ssp [Bertram et al., 1995]) and BOFS 8K (C. wuellerstorfi, this study). Holocene values are similar for the two cores. The glacial section is characterized by a strong gradient between the shallow and deep sites.

deeper core site reveals glacial values of around $0 \%$ whereas values from the shallow site are around $1.6 \%$. The enhanced gradient in benthic $\delta^{13} \mathrm{C}$ between shallow and deep sites reflects the stratification of the North Atlantic with respect to $\delta^{13} \mathrm{C}$ and nutrient distributions during of the glacial mode of circulation. A minimum in benthic $\delta^{13} \mathrm{C}$ in BOFS $17 \mathrm{~K}$ occurs during the period 15-18 ka (approximately equivalent to Heinrich event 1 [Sarnthein et al., 2000]). This phenomenon has been observed in several other cores in the eastern North Atlantic, most predominantly from sites above about $3 \mathrm{~km}$ water depth, and has been inferred to represent a major reduction in NADW production in the North Atlantic [Keigwin and Lehman, 1994; Vidal et al., 1997; Zahn et al., 1997]. A slight increase in $\delta^{13} \mathrm{C}$ is observed in BOFS $8 \mathrm{~K}$ at this time. Such an increase has not been noted previously. However, this core is somewhat deeper than most published deglacial benthic $\delta^{13} \mathrm{C}$ records that display a clear signal pertaining to $\mathrm{H} 1$.

[20] A recent study by Raymo et al. [2004], concerning vertical gradients in $\delta^{13} \mathrm{C}$ in the N. E. Atlantic throughout the Pleistocene, makes the suggestion that northern sourced deep waters can have highly variable $\delta^{13} \mathrm{C}$ values depending on the region and mode of deep water formation. It follows that such variability should be considered when interpreting records of benthic $\delta^{13} \mathrm{C}$ in terms of circulation changes. While this is obviously an important point, the main focus of that study was on intermediate depths $(1145-2301 \mathrm{~m})$. The deepest site in the study (DSDP $607 ; 41^{\circ} \mathrm{N}, 33^{\circ} \mathrm{W}$, $3427 \mathrm{~m}$ ) showed fluctuations that were arguably influenced by deep waters of a southern origin [Raymo et al., 2004]. As the study here focuses mainly on the difference between intermediate and deeper waters (1150 m versus $4045 \mathrm{~m}$ ) we suggest that we observe the varying influence of northern versus southern sourced deep waters related to changes in North Atlantic circulation.

\subsection{Records of Shell Weight and Deep Ocean $\left[\mathrm{CO}_{3}^{\bar{z}}\right]$}

[21] Records of shell weight from the North Atlantic reveal significant temporal variability (Figure 6). The two shallower cores (BOFS 17K and NEAP 8K) show a decrease in shell weight through the deglaciation which has been interpreted in terms of decreasing surface water $\left[\mathrm{CO}_{3}^{-}\right]$in parallel with increasing atmospheric $\mathrm{CO}_{2}$ [Barker and Elderfield, 2002]. The two deeper cores show a very different trend. The Holocene records show a decrease in shell weight from about $12 \mathrm{ka}$, in line with the shallower cores, but the deglaciation records show an increase in shell weights, opposite to the shallower sites. Shell weights of glacial age in BOFS $8 \mathrm{~K}$, the deepest core, are similar to those from the early Holocene in the same core. If these results were interpreted solely in terms of dissolution it would be concluded that no appreciable change in bottom water $\left[\mathrm{CO}_{3}^{-}\right]$occurred between glacial and Holocene times in the deep North Atlantic. From comparison with the shallowest site, BOFS $17 \mathrm{~K}$, it is clear, however, that glacial age shells from BOFS $8 \mathrm{~K}$ must have suffered significant weight loss through dissolution. SEM imagery provides qualitative evidence of this. A glacial age sample of G. bulloides from BOFS $17 \mathrm{~K}$ shows a heavily calcified outer structure with clear evidence of spine bases, typical of well-preserved shells (Figures 7a and 7b) [Dittert and Henrich, 2000], whereas a glacial sample from BOFS $8 \mathrm{~K}$ shows significant smoothing of the outer surface, loss of spine bases and etching of interpore areas (Figures $7 \mathrm{c}$ and $7 \mathrm{~d}$ ), indicative of partial dissolution [Dittert and Henrich, 2000].

[22] The $\Delta$ shell weight records display several significant features (Figures 8 and 9): a maximum at around $19 \mathrm{ka}$, followed by an overall decrease during the termination to a minimum in the early Holocene at around $10 \mathrm{ka}$. A sharp decrease occurs just prior to $17 \mathrm{ka}$, during the first half of the Heinrich 1 (H1) ice-rafting event. Using the alternate age model for $G$. bulloides, as described in section 2.2, results in a shift in the decrease of $\Delta$ shell weight toward the latter half of $\mathrm{H} 1$ (dashed line in Figure 9). These features are also apparent in the benthic $\Delta \delta^{13} \mathrm{C}$ record (Figure 9).

[23] Broecker and Clark [2001b] applied the shell weight method to a glacial time slice to reconstruct deep water $\left[\mathrm{CO}_{3}^{-}\right]$in the equatorial Atlantic. They observed a gradient in $\left[\mathrm{CO}_{3}^{\overline{ }}\right]$ in the glacial Atlantic similar to that expected from nutrient proxy reconstructions. However, shell weights from intermediate depths, being heavier than their modern counterparts, were interpreted as representing higher glacial $\left[\mathrm{CO}_{3}^{\overline{-}}\right]$ at these depths. Following Barker and Elderfield [2002], Broecker and Clark [2003] recalculated their shell weight data to allow for changes in initial weight and found that their weight measurements no longer demanded enhanced preservation at intermediate depths during glacial times. According to our study, $\Delta\left[\mathrm{CO}_{3}^{=}\right]\left(=\left[\mathrm{CO}_{3}^{=}\right]_{\text {in situ }}-\right.$ $\left.\left[\mathrm{CO}_{3}^{-}\right]_{\text {saturation }}\right)$ at the deepest site, BOFS $8 \mathrm{~K}$, reached an extreme value of $-24 \mu$ mol. $\mathrm{kg}^{-1}$ at about $19 \mathrm{ka}$ and had a mean value of about $-16 \mu \mathrm{mol} . \mathrm{kg}^{-1}$ during the Last Glacial 
Maximum (LGM) period (taken as 19-23 ka after Mix et al. [2001]) (Figure 9). This may be compared with an estimate of $-29 \mu \mathrm{mol} . \mathrm{kg}^{-1}$ at $4 \mathrm{~km}$ in the equatorial Atlantic during the LGM [Broecker and Clark, 2003]. Modern values
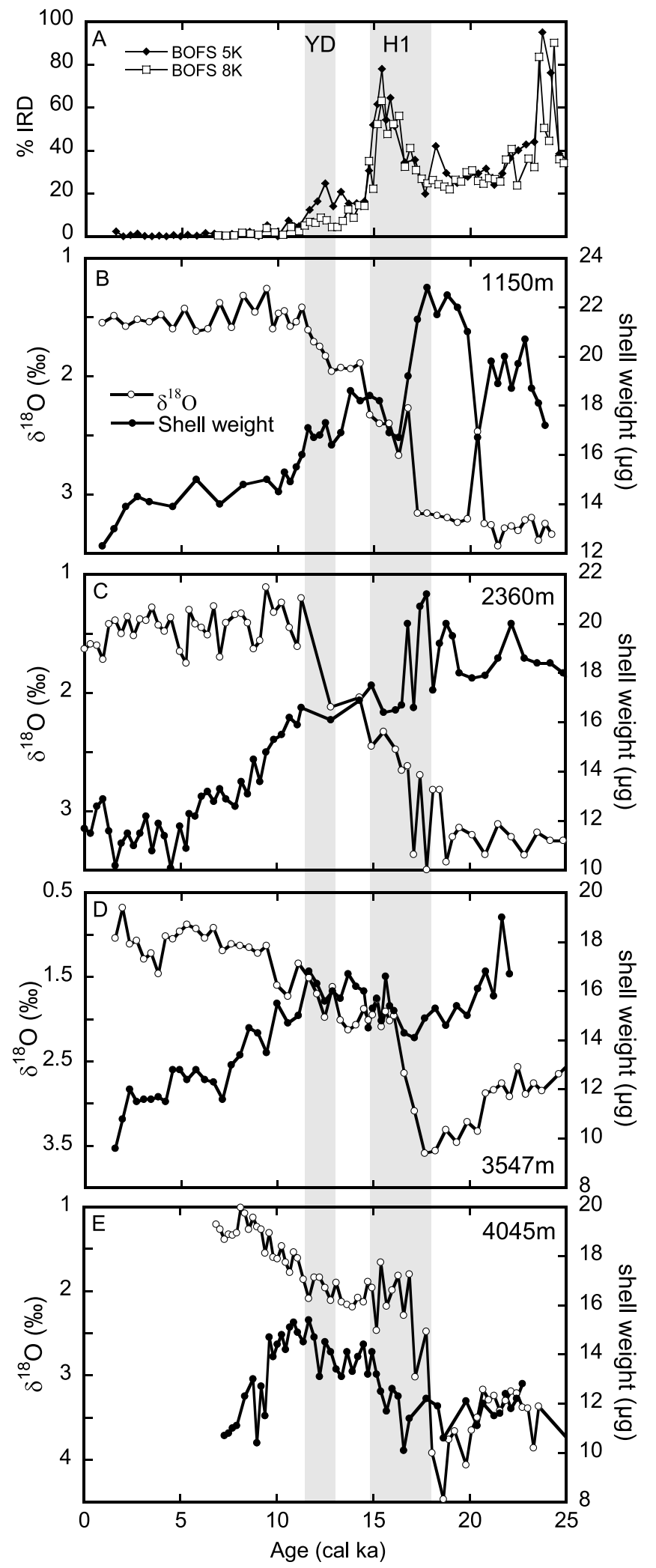

of $\left[\mathrm{CO}_{3}^{=}\right]$in the deep equatorial Atlantic are about $30 \mu \mathrm{mol} . \mathrm{kg}^{-1}$ lower than at $52^{\circ} \mathrm{N}$.

\subsection{Glacial-Interglacial Changes in Shell Weight}

[24] The records of shell weight shown in Figure 6 demonstrate clearly the interaction between initial weight variability and postdepositional weight loss due to dissolution. The similarity between all weight records during the Holocene suggests that their preservation histories were similar throughout this period although quite different before about $10 \mathrm{ka}$. It may be suggested that the glacial weight maximum from $20-17 \mathrm{ka}$, observed in the two shallowest cores, is a result of better preservation rather than changes in surface ocean $\left[\mathrm{CO}_{3}^{=}\right]$and initial weight variability. However, the site of NEAP 8K $(2360 \mathrm{~m})$ lies at or just below the glacial transition between UNADW and SOW [e.g., Oppo and Lehman, 1993]. This suggests that glacial age shells in this core would, if anything, be lighter were dissolution the only control on shell weight. Additionally, if core-top shells in BOFS $17 \mathrm{~K}$ (the shallowest core) had lost $45 \%$ by weight through dissolution (the glacial to Holocene difference) we may expect to observe physical evidence of dissolution, such as that illustrated in Figures $7 \mathrm{c}$ and $7 \mathrm{~d}$. Moreover, we should expect deeper sites to have dissolved to an even greater extent (with large offsets between all depths), due to the pressure dependence of $\mathrm{CaCO}_{3}$ solubility (given a modern vertical profile of in situ $\left[\mathrm{CO}_{3}^{-}\right]$). We do not observe these features.

[25] A potentially complicating factor is that of varying pore water/bottom water offsets in $\left[\mathrm{CO}_{3}^{=}\right] . \mathrm{CO}_{2}$ released during respiration of organic matter (so called respiratory $\mathrm{CO}_{2}$ ) within the upper few centimeters of the sediment column will tend to lower $\left[\mathrm{CO}_{3}^{\bar{*}}\right]$ within sediment pore waters and may lead to dissolution of carbonate [Emerson and Bender, 1981]. Assessing the influence of pore water dissolution in sediment cores is nontrivial. The extent of dissolution will depend variously on the relative rain rates of inorganic and organic carbon, the rates of oxic versus anoxic carbon degradation in the sediments and presumably the saturation state of overlying bottom waters [Archer, 1991]. Attempts to reconstruct glacial productivity in the North Atlantic have given ambiguous results [e.g., Coppedge and Balsam, 1992; Manighetti and McCave, 1995]. Organic carbon contents as a paleoproductivity indicator is complicated by the presence of terrigenous organic matter [Villanueva et al., 1997] but nevertheless should give some indication of the extent of respiratory $\mathrm{CO}_{2}$ available for pore water dissolution (although arguably it is the amount of organic matter that has been oxidized which is the controlling factor here, rather than that remaining). The organic and inorganic carbon deposition rates for the

Figure 6. Downcore records of shell weight and $\delta^{18} \mathrm{O}$ for G. bulloides (corrected for latitudinal offsets; see section 2.4). Differences between the records are due to differences in preservation between the sites. Deeper sites show a strong decrease in weight relative to the shallower sites during the glacial period. This reflects the incursion of corrosive southern sourced deep water into the North Atlantic at this time. 

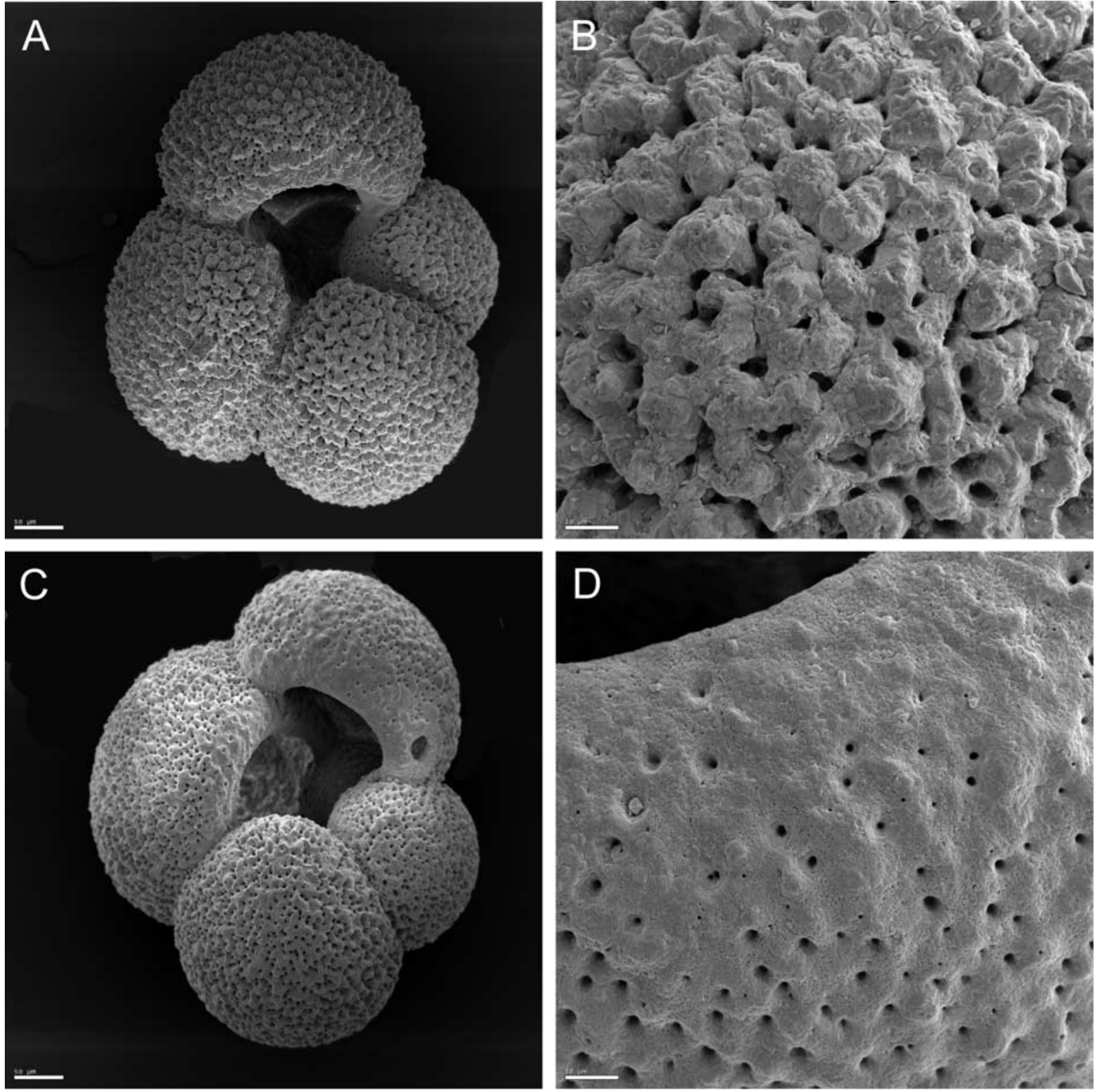

Figure 7. SEM images of $G$. bulloides from the glacial sections of (a and b) BOFS $17 \mathrm{~K}$ and (c and d) BOFS $8 \mathrm{~K}$. The specimen from the shallow site (BOFS 17K) shows a well-preserved heavily calcified external structure as compared to the deeper specimen which shows clear evidence of dissolution. Scale bars are $50 \mu \mathrm{m}$ in Figures $7 \mathrm{a}$ and $7 \mathrm{c}$ and $10 \mu \mathrm{m}$ in Figures $7 \mathrm{~b}$ and $7 \mathrm{~d}$.

BOFS cores were studied by Manighetti and McCave [1995]. Their results suggest that the flux of organic matter in BOFS $17 \mathrm{~K}$ was less (of the order $30-40 \%$ ) during the glacial period than during the Late Holocene (that in BOFS $8 \mathrm{~K}$ was increased by approximately the same proportion although BOFS $5 \mathrm{~K}$ also experienced a decrease). This may lead to the suggestion that increased glacial age shell weights in BOFS $17 \mathrm{~K}$ are a result of decreased dissolution in pore waters. However, the flux of inorganic carbonate to all locations in the study was reduced by an even greater extent (around $70 \%$ ) during the glacial period. This would mean that the rain ratio of organic to inorganic carbon most likely increased, leading to a possible increase in pore water dissolution in all sites. This discussion does not take into account more recent work by Armstrong et al. [2002] which suggests that the relative rain rates of organic and inorganic carbon arriving at the seafloor may actually be rather constant, due to the "ballasting" of organic matter by $\mathrm{CaCO}_{3}$.

[26] Recent genetic studies on planktonic foraminifera have revealed the existence of several subspecies (cryptospecies, or genotypes) of G. bulloides [Darling et al., 2003]. If different subspecies had fixed but distinct shell weights, it may be argued that the mean weight changes observed in this study are a result of changing surface water conditions and the relative contributions from two or more subspecies rather than changes in surface ocean carbonate chemistry 

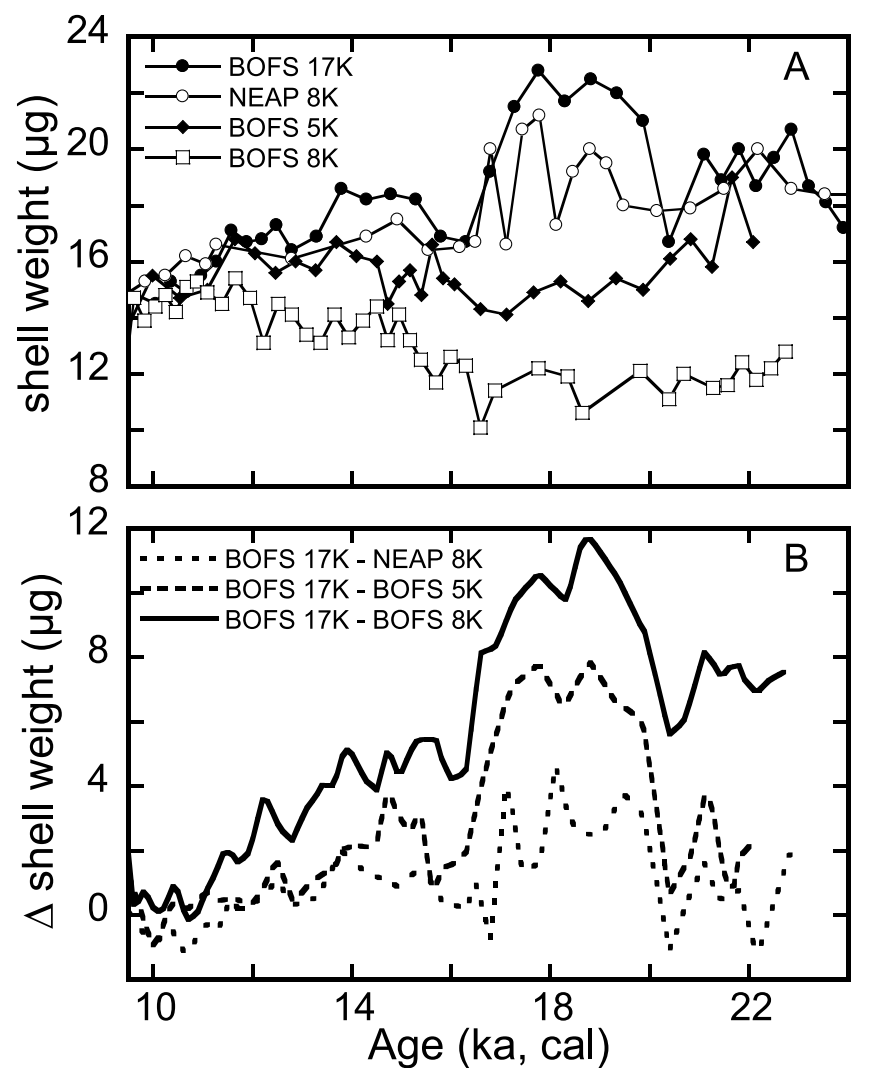

Figure 8. (a) Shell weights (corrected for latitudinal offsets) and (b) $\Delta$ shell weight records for the four cores. Calculation of $\Delta$ records is explained in section 2.6.

and or dissolution. In light of this possibility, several populations of $G$. bulloides from down core samples in ODP core $982\left(57.5^{\circ} \mathrm{N}, 15.9^{\circ} \mathrm{W}, 1134 \mathrm{~m}\right)$, situated very near to BOFS $17 \mathrm{~K}$, were analyzed for individual shell weights (Figure 10). The results from three intervals with differing mean population weight suggest a normal distribution within each sample. If the changes in weight were due to "endmember" mixing, a bimodal distribution may be expected.

[27] The presence of nutrient enriched, low $\delta^{13} \mathrm{C}$, waters at depth in the glacial North Atlantic (Figure 5) suggests a lowering of deep water $\left[\mathrm{CO}_{3}^{=}\right]$. This prediction is borne out by measurements of $\mathrm{Cd} / \mathrm{Ca}$ and $\mathrm{Zn} / \mathrm{Ca}$ in benthic foraminifera [Marchitto et al., 2002] and time slice reconstructions of bottom water $\left[\mathrm{CO}_{3}^{-}\right]$[Broecker and Clark, 2001b, 2003]. A lowering of $\left[\mathrm{CO}_{3}^{-}\right]$in the glacial deep North Atlantic would explain the dissolution of foraminiferal tests at the sites of BOFS $5 \mathrm{~K}$ and BOFS $8 \mathrm{~K}$ (Figure 8). The apparent weight loss in NEAP 8K during the period 17-20 ka may be a result of dissolution. Alternatively it may be an artefact of in-mixing of lighter shells since G. bulloides is relatively sparse in this section of the core. The same cannot be true of the two deeper cores since this process would tend to increase the average weight of glacial aged shells in these cores. In these cores the glacial weight loss is most likely to be a result of dissolution.

[28] Shell weights in the two shallowest cores show a decrease during $\mathrm{H} 1$. This could be interpreted as dissolution in the shallower cores, in response to a strongly reduced MOC during Heinrich events [e.g., McManus et al., 2004], rather than a decrease in initial shell weight. This would mean that deeper waters might not have experienced an increase in $\left[\mathrm{CO}_{3}^{\bar{亠}}\right]$ to the extent suggested by the $\Delta$ shell weight records. While this possibility is not unrealistic (benthic $813 \mathrm{C}$ at the site of BOFS $17 \mathrm{~K}$ does suggest the presence of less ventilated waters during $\mathrm{H} 1$ ) we would still expect a decrease in initial shell weight during H1 (shells in the shallow cores are lighter at the end of $\mathrm{H} 1$ than at the beginning). Since the two deeper records show a general increase in shell weight during the same interval, this still suggests that bottom waters at these sites became less corrosive during $\mathrm{H} 1$.

[29] Holocene shell weights in BOFS $17 \mathrm{~K}$ appear heavier than in the other cores after about $9 \mathrm{ka}$ (Figure 6). This could mean that dissolution has occurred in the three deeper sites for most of the Holocene but this would be contrary to studies which demonstrate that dissolution occurs only below about $4 \mathrm{~km}$ in the modern North Atlantic [Broecker and Clark, 2003]. As mentioned earlier, changes in surface temperature or nutrient gradients between sites may also play a role in determining offsets in shell weight between the cores. Since we have little way of determining and quantifying what such effects might be we can only highlight them as an uncertainty within our interpretation. It is clear that a future attempt to repeat this approach should exploit a depth transect of cores that underlies a very restricted surface area so as to further minimize possible offsets in initial shell weights. On the other hand, the major relative changes in (planktonic) shell weights between the shallow and deep sites during deglaciation are matched by relative changes in benthic $\delta^{13} \mathrm{C}$ between the same sites (Figure 9). This lends support to the suggestion that in general, weight differences are caused by the superposition of a "benthic" signal (i.e., dissolution) on the shell weight records from deeper sites rather than differences in initial weight.

\subsection{Records of $\Delta \delta^{13} \mathrm{C}$ and $\Delta$ Shell Weight}

[30] From the record of $\Delta \delta^{13} \mathrm{C}$ it can be inferred that the North Atlantic was most stratified with respect to nutrients between 18 and $20 \mathrm{ka}$ (Figure 9). The decrease in benthic ${ }^{13} \mathrm{C}$ in BOFS $17 \mathrm{~K}$ during $\mathrm{H} 1$ corresponds to a slight increase in $\delta^{13} \mathrm{C}$ in BOFS $8 \mathrm{~K}$, resulting in a decrease in the gradient between the two sites. A decrease in stratification might reflect increased vertical mixing in a stagnating water column or the increased dominance of southern sourced deep water throughout the North Atlantic basin during H1. In the latter case, the increase in $\delta^{13} \mathrm{C}$ at the deeper site would suggest that SOW was better ventilated with respect to its nutrient content during $\mathrm{H} 1$ than during the LGM. It is important to keep in mind that proxies for chemical stratification do not describe dynamic properties of oceanic circulation, i.e., increased stratification does not demand a sluggish circulation. In this case, maximum stratification occurred at the end of the LGM (18-20 ka) (while NADW production was active in the form of UNADW) and decreased throughout H1, presumably as a result of the reduction in UNADW production. The decrease in stratification into the Early Holocene then reflects the resumption of modern NADW formation. 

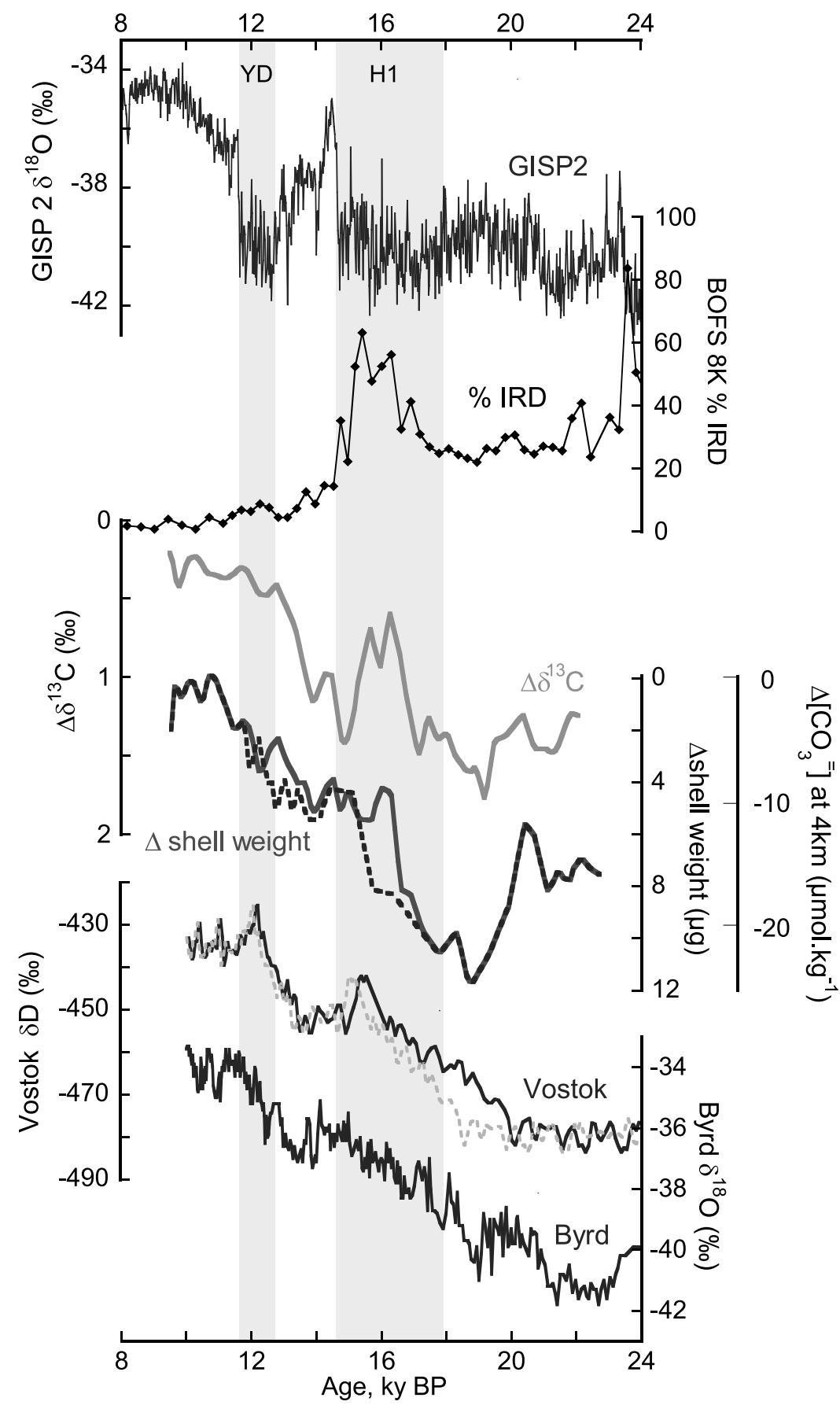

Figure 9. Plots of $\Delta \delta^{13} \mathrm{C}$ and $\Delta$ shell weight for BOFS $17 \mathrm{~K}$ and $8 \mathrm{~K}$. See text for explanation and note reversed scale. Dashed line in the $\Delta$ shell weight record represents the alternative age model constructed specifically for G. bulloides (see section 2.2). Also shown are $\delta^{18} \mathrm{O}$ values from the GISP 2 [Stuiver and Grootes, 2000] and Byrd [Johnsen et al., 1972] ice cores on the GISP 2 timescale [Meese et al., 1994; Blunier and Brook, 2001] and the $\delta \mathrm{D}$ record from Vostok [Jouzel et al., 1987]. The Vostok record is plotted on the GRIP timescale [Blunier et al., 1998] (dashed line) and on the GISP 2 timescale via $\mathrm{CH}_{4}$ correlation [Blunier and Brook, 2001] (solid line). See color version of this figure at back of this issue.

[31] A maximum in $\Delta \delta^{13} \mathrm{C}$ occurs during the period $13.5-15.5 \mathrm{ka}$, spanning the latter half of $\mathrm{H} 1$ and the Bølling interstadial. According to Sarnthein et al. [2000] the Holocene mode of the MOC started with full intensity at the onset of the Bølling interstadial at $14.7 \mathrm{ka}$ (prior to a partial collapse near the end of the YD). The maximum in our record of $\Delta \delta^{13} \mathrm{C}$ at this time appears to be mainly a function of deep water variability (the record of BOFS $8 \mathrm{~K}$ displays a temporary return to glacial values) although values from the shallow site are slightly higher than 

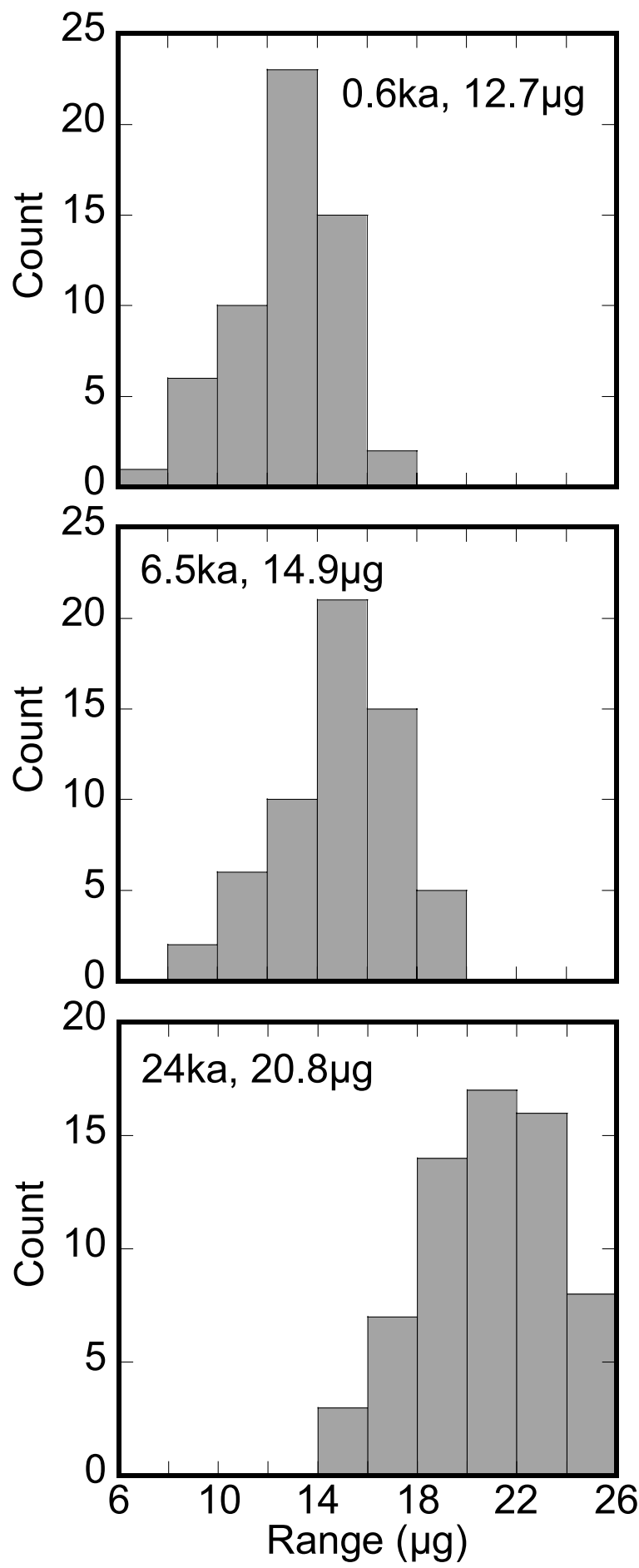

Figure 10. Histograms of individual shell weights of G. bulloides picked from ODP core 982 showing normal distribution of shell weights as the mean population weight increases from $0.6 \mathrm{ka}(12.7 \mu \mathrm{g})$ to $24 \mathrm{ka}(20.8 \mu \mathrm{g})$.

modern. This suggests that although deep water formation may have been active at this time, it had not reached the full extent of its modern mode with deeper waters still poorly ventilated with respect to intermediate and shallow depths. The record of $\Delta \delta^{13} \mathrm{C}$ reaches its minimum value (similar to that expected today) at around $10 \mathrm{ka}$, suggesting that the modern mode of MOC was probably active by this time.

[32] While the record of $\Delta$ shell weight describes the difference in preservation between the deep and shallow sites, it cannot be interpreted directly as the gradient in deep water $\left[\mathrm{CO}_{3}^{\bar{z}}\right]$. This is due to the pressure dependence of $\mathrm{CaCO}_{3}$ solubility. The concentration of $\mathrm{CO}_{3}^{=}$in the modern North Atlantic is fairly constant down to abyssal depths and at present no part of the water column is undersaturated with respect to $\mathrm{CaCO}_{3}$ (calcite). If the profile of $\left[\mathrm{CO}_{3}^{-}\right]$was shifted toward lower values without any change in gradient, deeper waters would become undersaturated significantly earlier than those at shallower depths. Thus dissolution at deeper depths does not necessarily imply a change in the gradient of $\left[\mathrm{CO}_{3}^{\overline{-}}\right]$. The site of BOFS $17 \mathrm{~K}(1150 \mathrm{~m})$ is presently bathed by NADW and was presumably under the influence of UNADW during the last glacial period. Since surface water $\left[\mathrm{CO}_{3}^{=}\right]$was probably higher during the glacial period [Sanyal et al., 1995; Lea et al., 1999], we should expect glacial UNADW to have had a similar or even higher $\left[\mathrm{CO}_{3}^{\overline{-}}\right]$ than modern NADW. This would suggest that the site of BOFS $17 \mathrm{~K}$ was safe from dissolution throughout the period of interest (but see section 3.3). If no weight loss has occurred in the shallow core, it may be argued that the calculated record of $\Delta$ shell weight is a record of weight loss in BOFS $8 \mathrm{~K}$ and is therefore a record of varying $\left[\mathrm{CO}_{3}^{\overline{-}}\right]$ at the deeper site (Figure 9).

[33] If the North Atlantic above about $2 \mathrm{~km}$ depth experienced an increase in $\left[\mathrm{CO}_{3}^{\bar{*}}\right]$ during the glacial then dissolution in the deeper sites (BOFS $5 \mathrm{~K}$ and $8 \mathrm{~K}$ ) does in fact reflect a change in the gradient of $\left[\mathrm{CO}_{3}^{\bar{z}}\right]$. This was observed by Broecker and Clark [2001b, 2003] and again reflects the incursion of SOW at depth. Our record of $\Delta$ shell weight may then be viewed as a function of SOW incursion into the deep northeast Atlantic. Since there is little known about absolute $\mathrm{CO}_{3}^{=}$concentrations of deep waters forming during the last glacial, the record of $\Delta$ shell weight should be considered as a qualitative record of SOW invasion. More strictly, the record is a combined function of the chemistry and northward flux of southern sourced waters.

[34] The record of $\Delta$ shell weight (Figure 9) suggests that maximum incursion of low $\left[\mathrm{CO}_{3}=\right.$ SOW occurred at around $19 \mathrm{ka}$, at the same time as the maximum in stratification recorded by $\Delta \delta^{13} \mathrm{C}$. Since this was a period of maximum dissolution in the deeper sites, due to maximum incursion of southern sourced deep water, we may expect to see a decrease in benthic $\delta^{13} \mathrm{C}$ in BOFS 8K; in fact a modest increase is observed after about $20 \mathrm{ka}$. A possible explanation for this discordancy may be the decoupling of $\delta^{13} \mathrm{C}$ and $\left[\mathrm{CO}_{3}^{=}\right] . \delta^{13} \mathrm{C}$ of dissolved inorganic carbon (DIC) in seawater is influenced by air-sea exchange, independent of biological interactions. In the modern ocean, high southern latitude surface waters have the highest (positive) values of ${ }^{13} C_{a s}$ (the air-sea exchange signature), mainly due to their low temperatures [Lynch-Stieglitz et al., 1995]. During glacial times the extent of sea-ice around Antarctica was significantly increased relative to today [Crosta et al., 1998; Gersonde et al., 2003]. This would have led to decreased air-sea exchange and therefore a decrease in $\delta^{13} C_{a s}$ [Stephens and Keeling, 2000]. The expected decrease of 
benthic $\delta^{13} \mathrm{C}$ in BOFS $8 \mathrm{~K}$ would have coincided with the onset of sea-ice reduction (and corresponding increase in $\left.\delta^{13} \mathrm{C}_{\mathrm{as}}\right)$ in the Southern Ocean at around $19 \mathrm{ka}$ as reconstructed by Shemesh et al. [2002]. Thus the two signals may act to cancel one another out. However, the same mechanism may well counter the argument for more corrosive bottom waters at this time since an increase in air-sea exchange (and concomitant decrease in surface ocean $p \mathrm{CO}_{2}$ ) would most likely lead to an increase in $\left[\mathrm{CO}_{3}^{\bar{z}}\right]$.

[35] $\Delta$ shell weight decreases during the first half of $\mathrm{H} 1$ in line with the decrease in $\Delta \delta^{13} \mathrm{C}$. Using the alternate age model for G. bulloides, as described in section 2.2, results in a shift in the decrease of $\Delta$ shell weight toward the latter half of H1 (dashed line in Figure 9). The decrease in weight loss could reflect a decline in southern sourced waters during H1. Alternatively the decrease in $\Delta$ shell weight may be the result of an increase in the $\left[\mathrm{CO}_{3}^{=}\right]$of SOW perhaps due to an increase in the flux (and corresponding reduction in aging) of this water mass during $\mathrm{H} 1$. If this is the case, it suggests that the shutdown of NADW production in the North Atlantic was accompanied by enhanced production of deep waters sourced from the south; a scenario reminiscent of the bipolar seesaw (or polar asynchroneity) hypothesis [Blunier et al., 1998; Broecker, 1998]. In light of this we have plotted $\delta^{18} \mathrm{O}$ values (indicative of temperature) from the GISP 2 [Stuiver and Grootes, 2000] and Byrd [Johnsen et al., 1972] ice cores and SD from Vostok [Jouzel et al., 1987] together with our delta weight and $\Delta \delta{ }^{13} \mathrm{C}$ records from the N. Atlantic (Figure 9). Comparison of the $\Delta$ shell weight curve with the isotope record from Greenland (GISP2) reveals little similarity. However, there is some similarity between the $\Delta$ shell weight and Antarctic temperature records. Perhaps it is not too surprising that the record of $\Delta$ shell weight, which is strongly influenced by the flux and chemistry of deep waters originating from the Antarctic region, should resemble Antarctic climatic variability.

[36] A recent study by McManus et al. [2004], based on ${ }^{231} \mathrm{~Pa} /{ }^{230} \mathrm{Th}$ ratios, provides compelling evidence that meridional overturning in the western North Atlantic at least, was shut down completely during H1 ( 17.5$14.7 \mathrm{ka}$ ). This scenario would lend support to the notion of a stagnating water column at this time rather than an increase in the presence of southern sourced deep water. Another study by Skinner and Shackleton [2004] suggests that ${ }^{14} \mathrm{C}$ ventilation ages of Atlantic deep waters may have significantly increased during the latter stages of $\mathrm{H} 1$, although this would not necessarily demand a more sluggish circulation (see Skinner and Shackleton [2004] for an explanation of the uncertainties involved in interpreting past ${ }^{14} \mathrm{C}$ ventilation ages). On the other hand, a study of paired benthic $\mathrm{Mg} / \mathrm{Ca}$ and $\delta^{18} \mathrm{O}$ measurements from a core off the Iberian margin (MD99-2334; $37.8^{\circ} \mathrm{N}, 10.2^{\circ} \mathrm{W}, 3146 \mathrm{~m}$ ) suggests that the deep N. E. Atlantic was dominated by cold, fresh, southern sourced deep waters during Northern Hemisphere stadial events over the last $34 \mathrm{ka}$ [Skinner et al., 2003]. This argues toward a more active circulation during H1. Our shell weight data adds some independent proxy evidence for a gradual reinforcement of ventilation of the deep Atlantic during $\mathrm{H} 1$, possibly by southern source water.
[37] The record of $\Delta$ shell weight shows a plateau during the maximum in $\Delta \delta^{13} \mathrm{C}$ in the latter part of $\mathrm{H} 1$ and the Bølling interstadial. Use of the alternative age model specifically for $G$. bulloides shifts this plateau to within the Bølling and earliest YD. The fact that dissolution occurred at the deeper sites during this period (weight loss is also apparent in BOFS $5 \mathrm{~K}$ ) confirms that the MOC had probably not fully recovered to its Holocene mode by this time.

[38] Records of benthic foraminiferal $\delta^{13} \mathrm{C}$ and $\mathrm{Cd} / \mathrm{Ca}$ from the west and central Atlantic [e.g., Boyle and Keigwin, 1987; Keigwin and Lehman, 1994; Marchitto et al., 1998] have been used to demonstrate a weakening of the MOC during the Younger Dryas (YD) period (11.6-12.9 ka [Hughen et al., 1996; Stuiver and Grootes, 2000]). While our records of $\Delta \delta^{13} \mathrm{C}$ and $\Delta$ shell weight suggest that circulation had not yet recovered to its Holocene mode during the YD they do not show any particular features that might be interpreted as a marked change in circulation at this time. A possible explanation for this is that the sedimentation rate in our cores is too low to detect a YD signal or that any signal has been lost due to bioturbation. Alternatively, the records suggest that any change in the MOC during the YD did not strongly affect the $\delta^{13} \mathrm{C}$ gradient and deep water $\left[\mathrm{CO}_{3}^{-}\right]$of the northeast Atlantic.

[39] Core-top weight data in the equatorial Atlantic imply that weight loss through dissolution commences below about $4 \mathrm{~km}$ in the modern ocean [Broecker and Clark, 2003]. The record of $\Delta$ shell weight attains its minimum value (approximately zero) at around $10 \mathrm{ka}$ (Figure 9) and suggests that a modern mode of MOC was probably active by about $10 \mathrm{ka}$.

\section{Conclusions}

[40] Records of shell weight in the North Atlantic demonstrate the interplay between initial weight variability and postdepositional weight loss. In order to interpret a record of shell weight in terms of preservation variability, it is necessary to account for any changes in initial shell weight. It has been demonstrated that these two signals can be differentiated by use of multiple records from proximal sites and different water depths.

[41] Results suggest that maximum incursion of SOW and stratification of the North Atlantic occurred between about $18-20 \mathrm{ka}$ defining the full glacial mode of the Atlantic MOC. During H1, chemical stratification was reduced and the deep North Atlantic became less corrosive. This could be interpreted as a reduction in the presence of SOW at this site and the homogenization of the North Atlantic while NADW production was switched off. Alternatively, it may reflect a change in the flux and chemistry of SOW during the period, suggesting enhanced production of southern sourced deep waters during the shutdown of NADW. The modern mode of the MOC was attained by about $10 \mathrm{ka}$ at the start of the Holocene period.

[42] Acknowledgments. We would like to thank Linda Booth and Heather Johnstone for their invaluable assistance in the laboratory and Mark Maslin for providing extensive data sets for the BOFS cores. We thank J. McManus for helpful discussions and two anonymous reviewers for their thoughtful comments. This study was partly funded by a Comer Rapid Climate Change Fellowship to SB and European Union grant EVRICT2001-40018 (CESOP). 


\section{References}

Alley, R. B., and P. U. Clark (1999), The deglaciation of the Northern Hemisphere: A global perspective, Annu. Rev. Earth Planet. Sci., 27, $149-182$.

Archer, D. (1991), Modeling the calcite lysocline, J. Geophys. Res., 96, 17,037-17,050.

Archer, D., S. Emerson, and C. Reimers (1989), Dissolution of calcite in deep-sea sediments: $\mathrm{PH}$ and $\mathrm{O}_{2}$ microelectrode results, Geochim. Cosmochim. Acta, 53, 2831-2845.

Armstrong, R. A., C. Lee, J. I. Hedges, S. Honjo, and S. G. Wakeham (2002), A new, mechanistic model for organic carbon fluxes in the ocean based on the quantitative association of POC with ballast minerals, Deep Sea Res. Part II, 49, 219-236.

Bard, E. (1988), Correction of accelerator mass spectrometry ${ }^{14} \mathrm{C}$ ages measured in planktonic foraminifera: Paleoceanographic implications, Paleoceanography, 3, 635-645.

Bard, E., F. Rostek, J. L. Turon, and S. Gendreau (2000), Hydrological impact of Heinrich events in the subtropical northeast Atlantic, Science, 289, 1321-1324.

Barker, S., and H. Elderfield (2002), Foraminiferal calcification response to glacial-interglacial changes in atmospheric $\mathrm{CO}_{2}$, Science, 297, 833-836.

Berger, W. H. (1970), Planktonic foraminifera: Selective solution and the lysocline, Mar. Geol., 8, 111-138.

Bertram, C. J., H. Elderfield, N. J. Shackleton, and J. A. Macdonald (1995), Cadmium/calcium and carbon-isotope reconstructions of the glacial northeast Atlantic Ocean, Paleoceanography, $10,563-578$

Beveridge, N. A. S., H. Elderfield, and N. J. Shackleton (1995), Deep thermohaline circulation in the low-latitude Atlantic during the Last Glacial, Paleoceanography, 10, 643-660.

Bijma, J., H. Spero, and D. W. Lea (1999), Reassessing foraminiferal stable isotope geochemistry: Impact of the oceanic carbonate system (experimental results), in Uses of Proxies in Paleoceanography: Examples From the South Atlantic, edited by G. Fischer and G. Wefer, pp. 489-512, Springer-Verlag, New York.

Bijma, J., B. Hönisch, and R. E. Zeebe (2002), Impact of the ocean carbonate chemistry on living foraminiferal shell weight: Comment on "Carbonate ion concentration in glacialage deep waters of the Caribbean Sea" by W. S. Broecker and E. Clark, Geochem. Geophys. Geosyst., 3(11), 1064, doi:10.1029/ 2002 GC000388.

Blunier, T., and E. J. Brook (2001), Timing of millennial-scale climate change in Antarctica and Greenland during the last glacial period, Science, 291, 109-112.

Blunier, T., et al. (1998), Asynchrony of Antarctic and Greenland climate change during the last glacial period, Nature, 394, 739-743.

Bond, G., et al. (1992), Evidence for massive discharges of icebergs into the north Atlantic Ocean during the Last Glacial Period, Nature, $360,245-249$.

Boyle, E. (1995), Last-Glacial-Maximum North Atlantic Deep Water: On, off or somewhere inbetween?, Philos. Trans. R. Soc. London Ser. $B, 348,243-253$.

Boyle, E. A., and L. D. Keigwin (1982), Deep circulation of the North Atlantic over the last 20,0000 years: Geochemical evidence, Science, 218, 784-787.

Boyle, E. A., and L. Keigwin (1987), North Atlantic thermohaline circulation during the past 20,000 years linked to high latitude surface temperature, Nature, 330, 35-40.

Broecker, W. S. (1998), Paleocean circulation during the last deglaciation: A bipolar seesaw?, Paleoceanography, 13, 119-121.

Broecker, W. S., and E. Clark (2001a), An evaluation of Lohmann's foraminifera weight dissolution index, Paleoceanography, 16, $531-$ 534.

Broecker, W. S., and E. Clark (2001b), Glacial to Holocene redistribution of carbonate ion in the deep sea, Science, 294, 2152-2155.

Broecker, W. S., and E. Clark (2003), Glacial age deep sea carbonate ion concentrations, Geochem. Geophys. Geosyst., 4(6), 1047, doi:10.1029/2003GC000506.

Coppedge, M. L., and W. L. Balsam (1992), Organic carbon distribution in the North Atlantic Ocean during the Last Glacial Maximum, Mar. Geol., 105, 37-50.

Crosta, X., J. J. Pichon, and L. H. Burckle (1998), Application of modern analog technique to marine Antarctic diatoms: Reconstruction of maximum sea-ice extent at the Last Glacial Maximum, Paleoceanography, 13, 284-297.

Darling, K. F., M. Kucera, C. M. Wade, P. von Langen, and D. Pak (2003), Seasonal distribution of genetic types of planktonic foraminifer morphospecies in the Santa Barbara Channel and its paleoceanographic implications, Paleoceanography, 18(2), 1032, doi:10.1029/ 2001PA000723.

Dittert, N., and R. Henrich (2000), Carbonate dissolution in the South Atlantic Ocean: Evidence from ultrastructure breakdown in Globigerina bulloides, Deep Sea Res. Part I, 47, 603-620.

Elderfield, H., and S. Barker (2001), Investigation of shell mass of planktonic foraminifera from water column and core tops in the North Atlantic Ocean, Eos Trans. American Geophysical Union, 82(47), Fall Meet. Suppl., Abstract PP12A-69.

Elliot, M., L. Labeyrie, and J. C. Duplessy (2002), Changes in North Atlantic Deep Water formation associated with the DansgaardOeschger temperature oscillations (60-10 ka), Quat. Sci. Rev., 21, 1153-1165.

Emerson, S., and M. Bender (1981), Carbon fluxes at the sediment-water interface of the deep sea: Calcium carbonate preservation, J. Mar. Res., 39, 139-162.

Gersonde, R., et al. (2003), Last glacial sea surface temperatures and sea-ice extent in the Southern Ocean (Atlantic-Indian sector): A multiproxy approach, Paleoceanography, 18(3), 1061, doi:10.1029/2002PA000809.

Haflidason, H., J. Eiriksson, and S. Van Kreveld (2000), The tephrochronology of Iceland and the North Atlantic region during the Middle and Late Quaternary: A review, J. Quat. Sci., $15,3-22$.

Hughen, K. A., J. T. Overpeck, L. C. Peterson, and S. Trumbore (1996), Rapid climate changes in the tropical Atlantic region during the last deglaciation, Nature, 380, 51-54

Jansen, E., and T. Veum (1990), Evidence for 2-step deglaciation and its impact on North Atlantic Deep Water circulation, Nature, 343, $612-616$.

Johnsen, S. J., W. Dansgaard, H. B. Clausen, and C. C. Langway (1972), Oxygen isotope profiles through the Antarctic and Greenland ice sheets, Nature, 235, 429-434

Jouzel, J., C. Lorius, J. R. Petit, C. Genthon, N. I. Barkov, V. M. Kotlyakov, and V. M. Petrov
(1987), Vostok ice core-A continuous isotope temperature record over the last climatic cycle (16,0000 years), Nature, 329, 403-408.

Keigwin, L. D., and S. J. Lehman (1994), Deep circulation change linked to Heinrich event 1 and Younger Dryas in a middepth North Atlantic core, Paleoceanography, 9, 185-194.

Keigwin, L. D., G. A. Jones, S. J. Lehman, and E. A. Boyle (1991), Deglacial meltwater discharge, North Atlantic deep circulation, and abrupt climate change, J. Geophys. Res., 96 , $16,811-16,826$.

Kroopnick, P. (1980), The distribution of ${ }^{13} \mathrm{C}$ in the Atlantic Ocean, Earth Planet. Sci. Lett., 49, 469-484.

Lea, D. W., J. Bijma, H. Spero, and D. Archer (1999), Implications of the carbonate ion effect on shell carbon for glacial ocean conditions, in Uses of Proxies in Paleoceanography: Examples From the South Atlantic, edited by G. Fischer and G. Wefer, pp. 513-522, SpringerVerlag, New York.

Lehman, S. J., and L. D. Keigwin (1992), Sudden changes in North Atlantic circulation during the last deglaciation, Nature, 356, 757762.

Lohmann, G. P. (1995), A model for variation in the chemistry of planktonic foraminifera due to secondary calcification and selective dissolution, Paleoceanography, 10, 445-457.

Lynch-Stieglitz, J., T. F. Stocker, W. S. Broecker, and R. G. Fairbanks (1995), The influence of air-sea exchange on the isotopic composition of oceanic carbon: Observations and modeling, Glob. Biogeochem. Cycle, 9, 653-665.

Manighetti, B., and I. N. McCave (1995), Depositional fluxes, palaeoproductivity, and ice rafting in the N. E. Atlantic over the past $30 \mathrm{Ka}$, Paleoceanography, 10, 579-592.

Manighetti, B., I. N. McCave, M. Maslin, and N. J. Shackleton (1995), Chronology for climate change: Developing age models for the Biogeochemical Ocean Flux Study cores, Paleoceanography, 10, 513-525.

Marchitto, T. M., W. B. Curry, and D. W. Oppo (1998), Millennial-scale changes in North Atlantic circulation since the last glaciation, Nature, 393, 557-561.

Marchitto, T. M. Jr., D. W. Oppo, and W. B. Curry (2002), Paired benthic foraminiferal $\mathrm{Cd} / \mathrm{Ca}$ and $\mathrm{Zn} / \mathrm{Ca}$ evidence for a greatly increased presence of Southern Ocean Water in the glacial North Atlantic, Paleoceanography, 17(3), 1038, doi:10.1029/2000PA000598.

Maslin, M. A. (1992), A study of the palaeoceanography of the N. E. Atlantic in the Late Pleistocene, Ph.D. thesis, Univ. of Cambridge, Cambridge, U.K.

Maslin, M. A., N. J. Shackleton, and U. Pflaumann (1995), Surface water temperature, salinity and density changes in the Northeast Atlantic during the last 45,000 years: Heinrich events, deep water formation and climatic rebounds, Paleoceanography, 10, 527-544.

McManus, J. F., R. Francois, J. M. Gherardi, L. D. Keigwin, and S. Brown-Leger (2004), Collapse and rapid resumption of Atlantic meridional circulation linked to deglacial climate changes, Nature, 428, 834-837.

Meese, D. A., A. J. Gow, P. Grootes, P. A. Mayewski, M. Ram, M. Stuiver, K. C. Taylor, E. D. Waddington, and G. A. Zielinski (1994), The accumulation record from the GISP 2 core as an indicator of climate change throughout the Holocene, Science, 266, 1680-1682.

Mix, A. C., E. Bard, and R. Schneider (2001), Environmental processes of the ice age: Land, 
oceans, glaciers (EPILOG), Quat. Sci. Rev., 20, 627-657.

Oppo, D. W., and S. J. Lehman (1993), Middepth circulation of the subpolar North Atlantic during the Last Glacial Maximum, Science, $259,1148-1152$.

Rahmstorf, S. (2002), Ocean circulation and climate during the past 12,0000 years, Nature, 419, 207-214.

Raymo, M. E., D. W. Oppo, B. P. Flower, D. A. Hodell, J. F. McManus, K. A. Venz, K. F. Kleiven, and K. McIntyre (2004), Stability of North Atlantic water masses in face of pronounced climate variability during the Pleistocene, Paleoceanography, 19, PA2008, doi:10.1029/2003PA000921.

Sanyal, A., N. G. Hemming, G. N. Hanson, and W. S. Broecker (1995), Evidence for a higher $\mathrm{pH}$ in the glacial ocean from boron isotopes in foraminifera, Nature, 373, 234-236.

Sarnthein, M., K. Winn, S. J. A. Jung, J. C. Duplessy, L. Labeyrie, H. Erlenkeuser, and G. Ganssen (1994), Changes in east Atlantic deep-water circulation over the last 30,000 years: Eight time slice reconstructions, Paleoceanography, 9, 209-267.

Sarnthein, M., et al. (2000), Fundamental modes and abrupt changes in North Atlantic circulation and climate over the last 60ky: Concepts, reconstruction and numerical modeling, in The Northern North Atlantic: A Changing Environment, edited by P. Schafer et al., pp. 365-410, Springer-Verlag, New York.

Shemesh, A., D. Hodell, X. Crosta, S. Kanfoush, C. Charles, and T. Guilderson (2002), Sequence of events during the last deglaciation in Southern Ocean sediments and Ant- arctic ice cores, Paleoceanography, 17(4), 1056, doi:10.1029/2000PA000599.

Skinner, L. C., and N. J. Shackleton (2004), Rapid transient changes in northeast Atlantic deep water ventilation age across Termination I, Paleoceanography, 19, PA2005, doi:10.1029/2003PA000983.

Skinner, L. C., N. J. Shackleton, and H. Elderfield (2003), Millennial-scale variability of deepwater temperature and $\delta^{18} \mathrm{O}_{\mathrm{dw}}$ indicating deep-water source variations in the Northeast Atlantic, 0-34 cal. ka BP, Geochem. Geophys. Geosyst., 4(12), 1098, doi:10.1029/ $2003 \mathrm{GC} 000585$.

Spero, H. J., J. Bijma, D. W. Lea, and B. E. Bemis (1997), Effect of seawater carbonate concentration on foraminiferal carbon and oxygen isotopes, Nature, 390, 497-500.

Stephens, B. B., and R. F. Keeling (2000), The influence of Antarctic sea ice on glacial-interglacial $\mathrm{CO}_{2}$ variations, Nature, 404, 171-174.

Stuiver, M., and P. M. Grootes (2000), GISP 2 oxygen isotope ratios, Quat. Res., 53, 277-283.

Stuiver, M., and P. J. Reimer (1993), Extended ${ }^{14} \mathrm{C}$ data-base and revised Calib $3.0{ }^{14} \mathrm{C}$ age calibration program, Radiocarbon, 35, 215230.

Stuiver, M., P. J. Reimer, E. Bard, J. W. Beck, G. S. Burr, K. A. Hughen, B. Kromer, G. McCormac, and M. Spurk (1998), INTCAL98 radiocarbon age calibration, 24,000-0 cal BP, Radiocarbon, 40, 1041-1083.

Veum, T., E. Jansen, M. Arnold, I. Beyer, and J. C. Duplessy (1992), Water mass exchange between the North Atlantic and the Norwegian Sea during the past 28,000 years, Nature, 356, $783-785$.
Vidal, L., L. Labeyrie, E. Cortijo, M. Arnold, J. C. Duplessy, E. Michel, S. Becque, and T. C. E. vanWeering (1997), Evidence for changes in the North Atlantic Deep Water linked to meltwater surges during the Heinrich events, Earth Planet. Sci. Lett., 146, 13-27.

Villanueva, J., J. O. Grimalt, E. Cortijo, L. Vidal, and L. Labeyrie (1997), A biomarker approach to the organic matter deposited in the North Atlantic during the last climatic cycle, Geochim. Cosmochim. Acta, 61, 4633-4646.

Voelker, A. H. L., P. M. Grootes, M. J. Nadeau, and M. Sarnthein (2000), Radiocarbon levels in the Iceland Sea from 25-53 kyr and their link to the Earth's magnetic field intensity, Radiocarbon, 42, 437-452.

Waelbroeck, C., J. C. Duplessy, E. Michel, L. Labeyrie, D. Paillard, and J. Duprat (2001), The timing of the last deglaciation in North Atlantic climate records, Nature, 412, 724-727.

Zahn, R., J. Schonfeld, H. R. Kudrass, M. H. Park, H. Erlenkeuser, and P. Grootes (1997), Thermohaline instability in the North Atlantic during meltwater events: Stable isotope and ice-rafted detritus records from core SO7526KL, Portuguese margin, Paleoceanography, $12,696-710$.

S. Barker, Lamont-Doherty Earth Observatory, Columbia University, Palisades, NY 10964 USA. (sbarker@ldeo.columbia.edu)

H. Elderfield and T. Kiefer, Department of Earth Sciences, University of Cambridge, Cambridge CB2 3EQ, UK. 


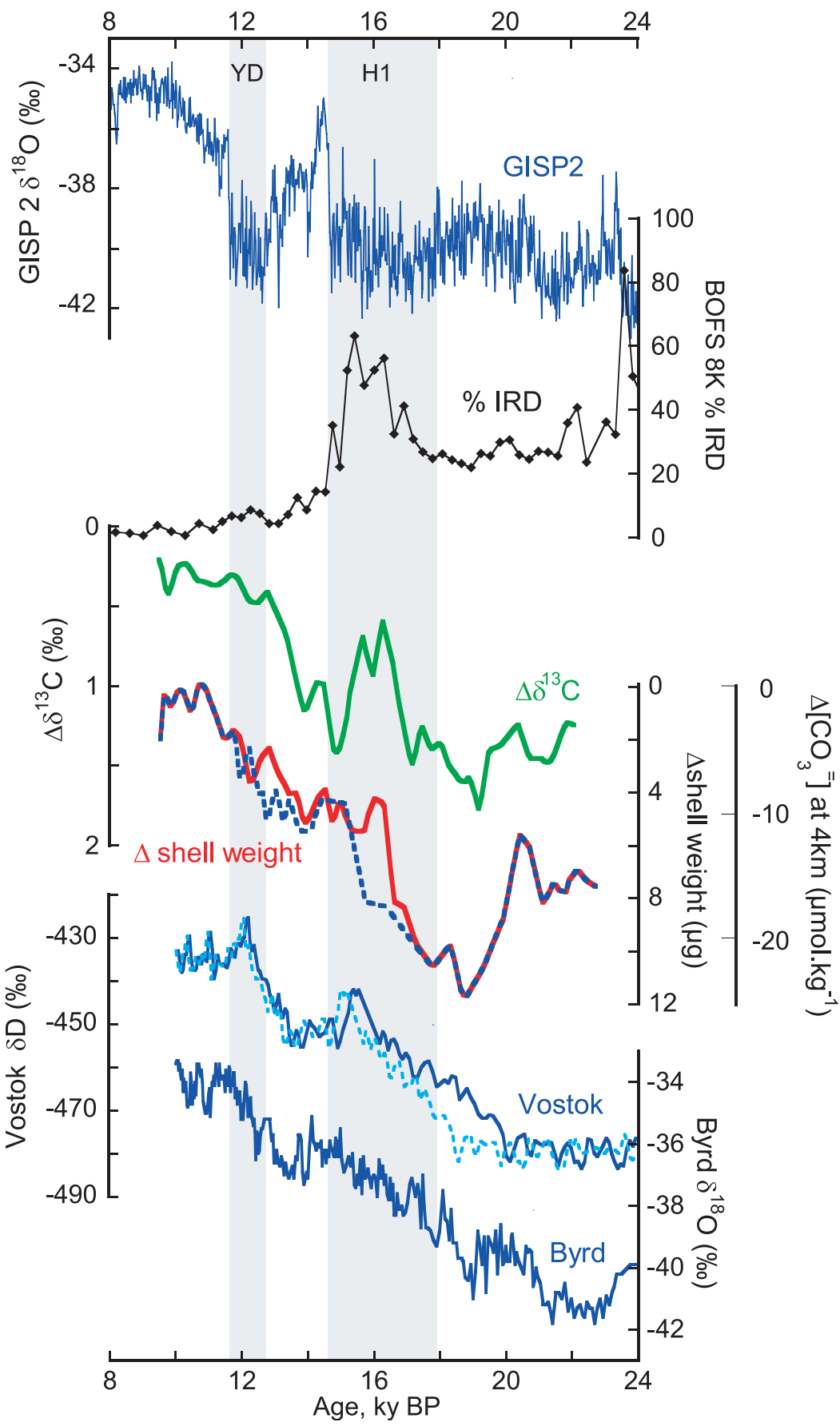

Figure 9. Plots of $\Delta \delta^{13} \mathrm{C}$ and $\Delta$ shell weight for BOFS $17 \mathrm{~K}$ and $8 \mathrm{~K}$. See text for explanation and note reversed scale. Dashed line in the $\Delta$ shell weight record represents the alternative age model constructed specifically for G. bulloides (see section 2.2). Also shown are $\delta^{18} \mathrm{O}$ values from the GISP 2 [Stuiver and Grootes, 2000] and Byrd [Johnsen et al., 1972] ice cores on the GISP 2 timescale [Meese et al., 1994; Blunier and Brook, 2001] and the $\delta \mathrm{D}$ record from Vostok [Jouzel et al., 1987]. The Vostok record is plotted on the GRIP timescale [Blunier et al., 1998] (dashed line) and on the GISP 2 timescale via $\mathrm{CH}_{4}$ correlation [Blunier and Brook, 2001] (solid line). 